\title{
Managerial risk-taking incentives and the systemic risk of financial institutions
}

\author{
Jamshed Iqbal $^{1}$ (D) . Sami Vähämaa ${ }^{1}$ (D) \\ Published online: 1 December 2018 \\ (c) The Author(s) 2018
}

\begin{abstract}
This paper examines whether the systemic risk of financial institutions is associated with the risk-taking incentives generated by executive compensation. We measure managerial risk-taking incentives with the sensitivities of chief executive officer (CEO) and chief financial officer (CFO) compensation to changes in stock prices (pay-performance sensitivity) and stock return volatility (pay-risk sensitivity). Using data on large U.S. financial institutions over the period 2005-2010, we document a negative association between systemic risk and the sensitivities of CEO and CFO compensation to stock return volatility. However, our results also demonstrate that financial institutions with greater managerial risk-taking incentives were associated with significantly higher levels of systemic risk during the peak of the financial crisis in 2008. We further document that the relation between pay-performance sensitivity and systemic risk is essentially nonexistent. Overall, our empirical findings indicate that the association between managerial risk-taking incentives and banks' systemic risk is ambiguous and is not stable over time.
\end{abstract}

Keywords Executive compensation - Risk-taking incentives $\cdot$ Systemic risk $\cdot$ Bank risktaking · Financial crisis

JEL Classification $\mathrm{G} 01 \cdot \mathrm{G} 20 \cdot \mathrm{G} 21 \cdot \mathrm{G} 30 \cdot \mathrm{G} 32 \cdot \mathrm{G} 34$

\section{Introduction}

"Compensation practices at some banking organizations have led to misaligned incentives and excessive risk-taking, contributing to bank losses and financial instability."

Chairman Ben S. Bernanke (Board of Governors of the Federal Reserve System 2009a)

Sami Vähämaa

sami@uva.fi

Jamshed Iqbal

jiqbal@uva.fi

1 School of Accounting and Finance, University of Vaasa, P.O. Box 700, 65101 Vaasa, Finland 
This paper examines whether the systemic risk of financial institutions is associated with the compensation-based risk-taking incentives of the top executives. In the aftermath of the global financial crisis of 2008-2009, policy makers, regulators, and bank supervision authorities have alleged that the risk-taking incentives generated by executive compensation policies at banking organizations were among the key factors contributing to the development of the crisis (see e.g., Kirkpatrick 2009; Basel Committee on Banking Supervision 2010; Board of Governors of the Federal Reserve System 2009b, 2010; Mehran et al. 2011). Furthermore, the financial crisis revealed the distinct adverse consequences of excessive bank risk-taking and systemic risk on global financial stability, economic growth, and societal well-being. Given that the compensation policies of top executives are generally designed to mitigate agency problems and to maximize shareholder value, the incentives generated by executive compensation may encourage excessive risk-taking in the financial industry (e.g., Palia and Porter 2004; Chen et al. 2006; Bebchuk et al. 2010; Bebchuk and Spamann 2010; Bai and Elyasiani 2013; Gande and Kalpathy 2017).

Do compensation-based risk-taking incentives of the top executives increase the riskiness of financial institutions and the level of systemic risk? In this paper, we aim to address this question by empirically examining the linkage between systemic risk and the sensitivities of chief executive officer (CEO) and chief financial officer (CFO) compensation to changes in stock prices and stock return volatility. ${ }^{1}$ Using data on large, publicly traded U.S. financial institutions, we find somewhat ambiguous evidence on the association between managerial risk-taking incentives and the systemic risk of financial institutions. Our results indicate that the sensitivities of top executive compensation to volatility are negatively related to systemic risk. However, our empirical findings also demonstrate that financial institutions with greater managerial risk-taking incentives were associated with significantly higher levels of systemic risk in 2008 during the peak of the global financial crisis.

Our analysis is closely related to the prior literature addressing the effects of managerial compensation structures on bank performance and risk-taking. ${ }^{2}$ Previous studies have examined how different elements of top executive compensation and the incentives generated by managerial compensation structures are reflected in the riskiness of financial institutions (e.g., Chen et al. 2006; DeYoung et al. 2013; Guo et al. 2015; Minhat and Abdullah 2016; Gande and Kalpathy 2017; Bharati and Jia 2018). Using data on U.S. commercial banks, Chen et al. (2006) document that option-based compensation and the option-based wealth of bank CEOs induce greater risk-taking. DeYoung et al. (2013) document that the compensation structures of CEOs are important determinants of bank business policies and risk-taking. Their findings also suggest that banks with higher CEO compensation sensitivities to volatility are associated with higher levels of systematic and idiosyncratic risk and are more involved with non-traditional banking activities. Guo et al. (2015) examine the relation between $\mathrm{CEO}$ compensation structure and bank risk-taking, and find that a higher proportion of incentive compensation increases default risk and stock return volatility.

The studies perhaps most related to our analysis are those of Bai and Elyasiani (2013) and Bharati and Jia (2018) which examine the linkages between CEOs' compensationbased risk-taking incentives and banks' default risk, stock return volatility, systematic risk,

\footnotetext{
1 We focus on CEO and CFO compensation incentives because they are arguably the most powerful executives within a firm and have substantial influence on corporate decisions and outcomes.

${ }^{2}$ Mehran et al. (2011) and de Haan and Vlahu (2016) provide comprehensive reviews of the link between executive compensation of risk-taking in the financial industry.
} 
and idiosyncratic risk. Bai and Elyasiani (2013) find that higher sensitivity of CEO compensation to stock return volatility induces risk-taking and leads to greater bank instability and higher levels of systematic as well as idiosyncratic risk. In contrast to Bai and Elyasiani (2013), Bharati and Jia (2018) document a negative relationship between systematic risk and the risk-sensitivity of CEO compensation, and find no association between idiosyncratic risk and managerial risk-taking incentives. We aim to contribute to the prior literature by examining the effects of managerial risk-taking incentives on the systemic risk of financial institutions.

Systemic risk can broadly be defined as a measure of interdependencies between the risk-taking of individual financial institutions and the overall riskiness of the financial system. Based on the prior literature about the effects of managerial compensation structures on bank risk-taking, we presume in this paper that managerial risk-taking incentives may influence the level of systemic risk. The risk-taking incentives generated by executive compensation are generally designed to maximize shareholder value by decreasing managerial risk aversion so that the managers would undertake risky, value-enhancing investments.

As noted by Fahlenbrach and Stulz (2011), among others, greater alignment of incentives between executives and shareholders in the financial industry may create a conflict between shareholder orientation and financial stability. Given the moral hazard problems in the financial industry caused by the too-big-to-fail phenomenon, implicit and explicit government guarantees, and deposit insurance systems, shareholder-oriented managerial compensation arrangements might encourage bank executives to adopt more risky business strategies and operations which, in turn, may lead to increased systemic risk. ${ }^{3}$ Because financial institutions and the executives of these institutions do not have to pay directly for the negative consequences of their excessive risk-taking, compensation-based managerial risk-taking incentives may not only increase the riskiness of an individual institution but also create negative externalities on the financial system by increasing the aggregate level of systemic risk. We therefore hypothesize that managerial risk-taking incentives are positively associated with the level of systemic risk.

In our empirical analysis, we use data on 71 large U.S. financial institutions over the period 2005-2010. Following the prior literature (e.g., Chava and Purnanandam 2010; Fahlenbrach and Stulz 2011; Bai and Elyasiani 2013; DeYoung et al. 2013; Minhat and Abdullah 2016; Gande and Kalpathy 2017), we measure the risk-taking incentives of the CEOs and CFOs with the sensitivities of their personal compensation to changes in the stock price and stock return volatility of their institutions. These two compensation sensitivities are commonly known as delta and vega. Delta is a relatively direct proxy for payperformance sensitivity and it provides a broad measure for how well top executive incentives are aligned with shareholder interests (e.g., Fahlenbrach and Stulz 2011). As noted for example by Bai and Elyasiani (2013), vega provides an explicit measure of the risksensitivity of executive compensation.

We measure the systemic risk of individual financial institutions with the market-based approach proposed by Acharya et al. (2012, 2017), and Brownlees and Engle (2017). ${ }^{4}$ Specifically, we use the marginal expected shortfall (MES) and systemic risk (SRISK) to gauge

\footnotetext{
3 Acharya $(2009,2011)$ provides a detailed discussion on how moral hazard problems and the too-big-tofail phenomenon may contribute to systemic risk.

4 Several alternative approaches for measuring systemic risk have been proposed in the literature in the aftermath of the global financial crisis. Different approaches are discussed and compared, for instance, in Bisias et al. (2012), Hattori et al. (2014), Kleinow et al. (2017), and Grundke (2018).
} 
systemic risk. MES measures the decline of a financial institution's equity capital when the market drops more than $2 \%$ and SRISK is the expected capital shortage of an institution during a financial crisis. Essentially, MES and SRISK aim to measure how exposed a given financial institution is to aggregate tail shocks in the financial system.

Our empirical findings indicate that the relationship between managerial risk-taking incentives and systemic risk is ambiguous. The results show that the sensitivities of top executive compensation to volatility (i.e., the CEO and CFO vegas) are generally negatively associated with systemic risk, while the relation between pay-performance sensitivity (i.e., the delta) and systemic risk is essentially nonexistent. Our regressions indicate that one standard deviation increases in CEO and CFO vegas are associated with approximately $6 \%$ reductions in SRISK. These findings are in stark contrast with the hypothesis that greater managerial risk-taking incentives would increase the level of systemic risk. Nevertheless, the documented negative association between vegas and banks' systemic risk is consistent with the alternative view is that compensation-based risk-taking incentives do not necessarily encourage risk-averse executives to increase firm risk-taking and may even induce executives to adopt less risky policies (e.g., Carpenter 2000; Ross 2004).

On the other hand, our empirical findings also demonstrate that the relationship between managerial risk-taking incentives and banks' systemic risk is not stable over time. We find that financial institutions with greater managerial risk-taking incentives were associated with significantly higher levels of systemic risk in 2008 during the peak of the global financial crisis. The positive association between the pre-crisis deltas and vegas of the top executives and systemic risk during the crisis is economically significant; our estimates indicate that a one standard deviation increase in deltas and vegas increases $M E S$ by about 25-40 basis points during the crisis. The documented positive association between CEO and CFO risk-taking incentives and systemic risk during the severe market turmoil in 2008 may indicate that financial institutions with greater compensation-based managerial risktaking incentives were taking more risk before the crisis in order to maximize shareholder wealth, and that these risks were then materialized and exposed during the financial crisis. This interpretation of our results is broadly consistent with the previous studies which suggest that banks with more shareholder-focused corporate governance structures were taking more risk before the crisis (e.g., Fortin et al. 2010; Erkens et al. 2012; Peni and Vähämaa 2012).

The remainder of the paper proceeds as follows. Section 2 reviews the related literature on managerial risk-taking incentives, the linkages between executive compensation and bank outcomes during the global financial crisis, and firm-specific attributes of systemic risk. Section 3 describes the data and introduces the variables used in our empirical analysis. Section 4 presents the methods and reports our empirical findings on the association between managerial risk-taking incentives and the systemic risk of financial institutions. Finally, the Sect. 5 summarizes the findings and concludes the paper.

\section{Related literature}

Our study builds upon several strands of research. In addition to the prior literature addressing the effects of managerial compensation structures on bank performance and risk-taking discussed in the introduction (e.g., Chen et al. 2006; DeYoung et al. 2013; Guo et al. 2015; Minhat and Abdullah 2016; Gande and Kalpathy 2017; Bharati and Jia 2018), our empirical analysis is closely related to three broad streams of research. First, we draw on the prior 
literature examining the linkages between executive compensation policies and firm risktaking. Since the risk-taking incentives generated by executive compensation are designed to decrease managerial risk aversion, it is not surprising that these risk-taking incentives have been abundantly documented to have a positive impact on the riskiness of non-financial firms (see e.g., Rajgopal and Shevlin 2002; Coles et al. 2006; Chava and Purnanandam 2010; Armstrong and Vashishtha 2012; Alam et al. 2015).

Nevertheless, the less recognized alternative view is that compensation-based risk-taking incentives do not necessarily encourage risk-averse executives to increase firm risktaking and may even induce executives to adopt less risky policies (e.g., Carpenter 2000; Meulbroek 2001; Ross 2004; Hayes et al. 2012). Although most empirical studies have linked higher managerial risk-taking incentives to higher stock return volatility and riskier corporate policies, many recent papers have documented a nonexistent or even a negative relationship between managerial risk-taking incentives and firm risk-taking, and have also documented that risk averse executives may offset compensation-based risk-taking incentives by adopting less risky financial policies (e.g., Serfling 2014; Bharati and Jia 2018; Doukas and Mandal 2018; Feng and Rao 2018; Chakraborty et al. 2018).

Despite the ample empirical literature on managerial risk-taking incentives in nonfinancial firms, surprisingly little attention has so far been devoted to the compensationbased risk-taking incentives in financial institutions. Banks and other financial institutions are fundamentally different from non-financial firms in terms of their business models, opaqueness, exposure to regulations and supervision, societal importance as well as amplified risk-taking incentives due to the implicit and explicit government guarantees and deposit insurance systems. Moreover, in contrast to non-financial firms, the additional regulatory oversight of financial institutions also encompasses their managerial compensation structures. ${ }^{5}$ Thus, more research is warranted on the implications of the managerial risktaking incentives in financial institutions.

Our study is closely related to the literature that examines linkages between executive compensation structures and bank outcomes during the global financial crisis of 2008-2009. The prior studies by Bebchuk et al. (2010), Fortin et al. (2010), Fahlenbrach and Stulz (2011), Bhagat and Bolton (2014), Minhat and Abdullah (2016), and Gande and Kalpathy (2017) provide somewhat mixed evidence about the effects of managerial compensation incentives on bank performance and riskiness amidst the crisis. Bebchuk et al. (2010) investigate the compensation structures of the top executives in Bear Stearns and Lehman Brothers, and conclude that the compensation arrangements in those banks may have provided excessive risk-taking incentives for the top executives. Fortin, Goldberg and Roth (2010) examine the determinants of bank risk-taking at the onset of the global financial crisis. Their empirical findings indicate that banks with higher CEO option-based compensation and bonuses were associated with greater risk-taking.

Fahlenbrach and Stulz (2011) investigate the influence of CEO compensation on the stock returns and profitability of U.S. banks during the financial crisis. In contrast to the view that managerial compensation incentives encouraged excessive risk-taking, Fahlenbrach and Stulz (2011) document that option-based compensation incentives and cash bonuses were unrelated to bank performance during the crisis. Using data on 14 of the largest U.S. financial institutions, Bhagat and Bolton (2014) find evidence that the incentives generated by executive compensation led to greater bank risk-taking and contributed

\footnotetext{
5 The 2010 Dodd-Frank Wall Street Reform and Consumer Protection Act, for instance, stipulates enhanced oversight of executive compensation structures in financial institutions.
} 
to the outbreak of the financial crisis. Minhat and Abdullah (2016) document that managerial risk-taking incentives induced by stock options are positively associated with banks' stock return volatility and insolvency risk. However, their findings also demonstrate that the relation between risk-taking incentives and bank risk is not stable over time. Finally, Gande and Kalpathy (2017) document that CEO equity incentives before the global financial crisis are positively associated with the amount of Federal Reserve emergency loans banks obtained during the crisis.

Finally, our study complements the growing body of literature that examines how certain firm-specific attributes are related to the systemic risk of financial institutions. Studies by Brunnermeier et al. (2012), Pais and Stork (2013), Mayordomo et al. (2014), Calluzzo and Dong (2015), and Acharya and Thakor (2016), among others, have documented that the size of the institution, the amount of equity capital, and the extent of lending activities are important factors for explaining the cross-sectional variation in systemic risk. These studies indicate larger institutions with lower capital ratios and greater involvement in nontraditional banking activities are associated with higher levels of systemic risk. Closely related to our analysis, Iqbal et al. (2015) and Battaglia and Gallo (2017) examine the relationship between shareholder-focused corporate governance structures and systemic risk. Their empirical findings suggest that financial institutions with more shareholder-oriented corporate governance mechanisms and boards of directors are associated with greater systemic risk. In this paper, we aim to extend the prior literature by examining the linkage between systemic risk and the compensation-based risk-taking incentives of the top executives.

\section{Data and variables}

We use data on 71 large, publicly traded U.S. financial institutions spanning the period 2005-2010. The data on CEO and CFO compensation, systemic risk, and financial statement and balance sheet variables of the financial institutions are obtained from S\&P Capital IQ's ExecuComp, the V-Lab of the Stern School of Business of New York University, and the Bureau van Dijk Bankscope, respectively. Our initial sample consists of the 98 financial institutions examined in Fahlenbrach and Stulz (2011) and we eliminate from this initial sample the institutions with missing or insufficient executive compensation and systemic risk data on Execucomp and/or V-Lab. This leaves us with a sample of 71 individual financial institutions and an unbalanced panel of 332 firm-year observations. ${ }^{6}$ The sample includes commercial banks, investment banks, non-bank lending institutions, and financial services firms. The list of financial institutions included in the sample is presented in "Appendix 1".

\subsection{Systemic risk}

Our dependent variable is the systemic risk of individual financial institutions. Systemic risk can be broadly defined as a measure of the relation of a particular financial institution's

\footnotetext{
${ }^{6}$ Several recent studies have used relatively small samples of financial institutions (see e.g., Chen et al. 2006; Fortin et al. 2010; Fahlenbrach and Stulz 2011; Adams and Mehran 2012; Peni and Vähämaa 2012; Peni et al. 2013; Mayordomo et al. 2014; Iqbal et al. 2015).
} 
risk-taking to the overall risk-taking in the financial industry. The systemic risk of an individual financial institution can be regarded as the contribution of the institution to the downside risk of the entire financial system (Anginer et al. 2014). The global financial crisis prompted considerable interest in the measurement of systemic risk and several alternative risk metrics have been proposed in the literature in recent years (for surveys, see e.g. Bisias et al. 2012 and Hattori et al. 2014). These alternative approaches to measuring systemic risk can be classified into accounting-based and market-based risk measures. The accounting-based systemic risk measures are estimated from balance sheet variables and are by construction backward-looking, while the market-based measures utilize financial market data and can thereby provide a timelier estimate of systemic risk.

In our empirical analysis, we apply the market-based approach developed by Acharya et al. (2012, 2017), and Brownlees and Engle (2017) to gauge systemic risk. Specifically, we utilize the marginal expected shortfall (MES) and systemic risk (SRISK) obtained from the NYU Stern's V-Lab to measure the systemic risk of individual financial institutions. These two systemic risk metrics are estimated from stock market data and attempt to capture the capital shortfall of an institution during periods of market stress based on its stock return volatility and correlation with the market. Essentially, MES and SRISK measure how exposed a given financial institution is to aggregate tail shocks in the stock markets. We use the year-end (December) estimates of MES and SRISK as the dependent variable in our analysis.

SRISK can be defined as the amount of "capital that a firm is expected to need if we have another financial crisis" (Acharya et al. 2012). Formally, SRISK for a financial institution $i$ at time $t$ can be expressed as:

$$
\operatorname{SRISK}_{i, t}=E_{i, t}(\text { Capital Shortfall } \mid \text { Crisis })
$$

Capital Shortfall in Eq. (1) is determined under the assumption that the book value of debt of a financial institution would remain relatively unchanged if a crisis occurred within the next 6 months whereas the value of equity would decline. The computation of SRISK is based on $M E S$ which measures the expected loss of equity capital during periods of market stress. $M E S$ can be broadly interpreted as the marginal contribution of an individual financial institution to the overall systemic risk, with higher $M E S$ reflecting a greater contribution of the institution to the aggregate level of systemic risk. If a financial institution has high levels of $M E S$, most of the institution's equity capital will be depleted during a financial crisis, and hence, the institution will be in danger of failure. This also implies that undercapitalization of financial institutions contributes positively to the overall systemic risk in the financial system (Brownlees and Engle 2017).

Acharya et al. (2012) define $M E S$ as the expected daily percentage decrease in the value of equity of an individual financial institution when the aggregate stock market declines by more than 2\%. By extrapolating MES to a longer and more severe period of market stress, Acharya et al. (2012) obtain the long run marginal expected shortfall (LRMES) which can be approximated as:

$$
\operatorname{LRMES}_{i, t}=1-\exp \left(-18 \times M E S_{i, t}\right)
$$

Based on LRMES, Acharya et al. (2012) estimate SRISK of financial institution $i$ at time $t$ as follows:

$$
\begin{aligned}
& \text { SRISK }_{i, t}=E_{i, t}\left[k\left(\text { Debt }_{i, t}+\text { Equity }_{i, t}\right)-\text { Equity }_{i, t} \mid \text { Crisis }\right] \\
& \text { SRISK }_{i, t}=k\left(\text { Debt }_{i, t}\right)-(1-k)\left(1-\text { LRMES }_{i, t}\right) \text { Equity }_{i, t}
\end{aligned}
$$


where $k$ denotes the prudential capital ratio which is taken to be $8 \%, L R M E S$ is the long run marginal expected shortfall, Equity is the market value of equity, and Debt is the market value of debt. Hence, SRISK is the amount of equity capital needed by a financial institution in a severe crisis in which the current equity value falls according to the LRMES and the level of debt stays constant.

$M E S$ and SRISK are estimated from historical stock price data. First, MES, or the expected daily decrease in equity value of a financial institution when the aggregate stock markets declines by more than $2 \%$ is calculated based on the institution's stock return volatility, correlation with the aggregate market, and extreme stock price movements. Then, these MES estimates are extrapolated to a financial crisis. Based on these extrapolated decreases in equity value, and under the assumption that a financial institution needs at least $8 \%$ of equity capital relative to the value of assets, SRISK is computed as the expected amount of equity capital that the institution would need to raise during a severe financial crisis. A more detailed description of the estimation of MES and SRISK can be found in Acharya et al. (2012, 2017), and Brownlees and Engle (2017).

\subsection{CEO and CFO risk-taking incentives}

The main independent variables in our empirical analysis are measures of risk-taking incentives generated by executive compensation. Following the prior literature on compensation-based incentives (see e.g., Chava and Purnanandam 2010; Fahlenbrach and Stulz 2011; Kini and Williams 2012; Shaw 2012; DeYoung et al. 2013; Minhat and Abdullah 2016; Gande and Kalpathy 2017; Hu and Jiang 2018; Yung and Chen 2018), we measure the risk-taking incentives of the CEOs and CFOs with the sensitivities of their personal compensation to changes in the stock price and stock return volatility of their institutions. More specifically, we utilize the delta and vega of the stock option holdings of individual executives as proxies for the compensation-based risk-taking incentives of the top executives.

CEO delta and $C F O$ delta measure the dollar gain or loss in personal executive wealth for a $1 \%$ change in the stock price of the financial institution. Consequently, delta is a relatively direct proxy for pay-performance sensitivity and it provides a broad measure of how well managerial incentives are aligned with shareholder interests (e.g., Fahlenbrach and Stulz 2011). The delta also provides an indirect measure of managerial risk-taking incentives because in order to increase shareholder wealth and their own compensation, the top executives are incentivized to take risks that ultimately increase the overall risk exposure of the firm (Chava and Purnanandam 2010; Kini and Williams 2012). CEO vega and CFO vega measure the dollar gain or loss in personal executive wealth for a $1 \%$ point change in the stock return volatility of the financial institution. As discussed by Bai and Elyasiani (2013), vega is an explicit measure of risk-sensitivity of executive compensation, and thereby it provides a direct proxy for the compensation-based risk-taking incentives of the top executives.

We follow the approach of Core and Guay (2002) and Fahlenbrach and Stulz (2011) to calculate the deltas and vegas for the top executives in each financial institution. Specifically, we collect data on the components of CEO and CFO compensation from 
ExecuComp. ${ }^{7}$ The deltas and vegas are calculated based on the Black-Scholes option valuation model using detailed information on fiscal year-end outstanding option grants awarded to the CEOs and CFOs. ${ }^{8}$ For each option grant, we obtain the strike prices and expiration dates from ExecuComp. We use the fiscal year-end stock price and stock return volatility over the previous 3 years as the Black-Scholes inputs for stock price and volatility, and the 10-year Treasury rate is used as a proxy for the risk-free interest rate. With these inputs, the deltas and vegas can be computed as the first partial derivatives of the Black-Scholes model with respect to stock price and volatility, respectively. By aggregating the deltas and vegas on each option grant for each executive, we are able to measure the changes in personal executive wealth associated with changes in stock price and stock return volatility.

\subsection{Control variables}

We employ a number of control variables in our empirical analysis to account for the potentially confounding effects of institution-specific factors on the level of systemic risk. Previous studies have documented that the riskiness of financial institutions is related to variables such as size, capital ratio, profitability, growth, and asset and income structure (see e.g., Pathan 2009; Fortin et al. 2010; Brunnermeier et al. 2012; Bai and Elyasiani 2013; Iqbal et al. 2015; Akhigbe et al. 2016; Berger et al. 2016; Ahmed et al. 2019).

Firm size is often considered the most important control variable when comparing financial institutions because different sized organizations may have very different characteristics, business strategies, governance mechanisms, and product compositions (Peni et al. 2013; Palvia et al. 2015). Moreover, larger institutions are likely to have greater systemic importance. Following the prior banking literature (e.g., Laeven and Levine 2009; DeYoung et al. 2013; Ellul and Yerramilli 2013; Akhigbe et al. 2016), we measure the size of the financial institutions (Size) by the natural logarithm of total assets. With respect to systemic risk, Brunnermeier et al. (2012), Pais and Stork (2013), and Iqbal et al. (2015) document that larger financial institutions are associated with higher levels of systemic risk, while Mayordomo et al. (2014) do not find any significant relation between systemic risk and bank size.

The second important variable that needs to be controlled for when comparing financial institutions is the amount of equity capital. The capital ratio is the main variable of interest for banking supervisors and regulators. The amount of equity capital is the predominant factor in reducing insolvency risk and capital ratio can be considered as a proxy for the soundness and financial health of the institution. We measure Capital ratio as the ratio of equity capital to total assets. Brownlees and Engle (2017) posit that the degree of undercapitalization of financial institutions reflects the level of systemic risk in the entire financial system. Moreover, Acharya and Thakor (2016), Brunnermeier et al. (2012), and

\footnotetext{
${ }_{7}$ To ensure that we have the correct CEOs and especially CFOs, we manually match the names of the CEOs and CFOs from the proxy statements of the financial institutions.

${ }^{8}$ In 2004, the Financial Accounting Standards Board (FASB) issued FAS 123R and the Securities and Exchange Commission (SEC) adopted new disclosure requirements for executive compensation that require firms to report detailed information on the compensation of at least five highest-paid executives. Given these disclosure requirements, firms have to report outstanding equity awards at fiscal year-end by providing detailed information about outstanding option grants, including the exercise prices and expiration dates of the options.
} 
Mayordomo et al. (2014) have documented that capital ratio is an important factor for explaining the systemic risk of individual financial institutions.

Furthermore, following the prior bank risk-taking literature, we control for the financial performance, growth, and asset and income structure of the financial institutions. We measure profitability of the institutions with Return on assets which is computed as the ratio of net income to total assets. Profitability can be seen as a crude proxy of management quality and more profitable institutions may be in better positions to build capital buffers and to reduce systemic risk. Previous studies have documented a negative association between profitability and systemic risk (Iqbal et al. 2015; Berger et al. 2016). We use the annual percentage change in the amount of outstanding loans as a proxy for the growth of the institutions (Growth). The growth rate is an important determinant of the riskiness of financial institutions (Foos et al. 2010). We utilize the ratio of net loans to total assets (Loans to assets) and total deposits divided by total assets (Deposits to assets) to control for the asset and liability structures of the financial institutions. These variables reflect the lending and funding risks of the institutions. Finally, we use the ratio of non-interest income to total income (Non-interest income) to control for the level of income diversification and the differences in business models across institutions. The balance sheet and income statement data for our control variables are collected from the Bureau van Dijk Bankscope.

\section{Empirical analysis}

\subsection{Descriptive statistics and correlations}

Table 1 reports the descriptive statistics for the variables used in our empirical analysis. The table illustrates that the financial institutions in our sample are very heterogeneous in terms of the compensation-based risk-taking incentives of their top executives. CEO delta takes values from a minimum of about USD 700 to a maximum of USD 53.1 million, while CFO delta takes varies between USD 50 and USD 38.2 million. The mean CEO delta of USD 1.6 million is about four times larger than the mean CFO delta of USD 400,000, and also the mean $C E O$ vega of USD 320,000 is approximately four-fold compared to the mean CFO vega of USD 81,000. The mean and median values of the CEO deltas and vegas over the sample period are plotted in Fig. 1. Regarding the systemic risk measures, Table 1 shows that our sample contains financial institutions associated with very different levels of systemic risk. MES varies from a minimum of $0.8 \%$ to a maximum of $8.7 \%$ with a mean of $2.5 \%$, while SRISK ranges from -67.7 billion to 136.5 billion with a mean value of 4.1 billion USD.

The descriptive statistics for the control variables in Table 1 demonstrate that our sample comprises very divergent types of financial institutions. Although all firms in our sample are large, publicly traded financial institutions, the amount of total assets (Size) varies substantially from about USD 540 million to USD 3.2 trillion. The inclusion of commercial banks as well as other types of financial institutions (investment banks, non-bank lending institutions, and financial services firms) in our sample is manifested in the considerable variation of the asset and income structure variables (Loans to assets, Deposits to assets, and Non-interest income). Overall, it can be concluded from the descriptive statistics that our empirical analysis is based on a heterogeneous sample of financial institutions.

Pairwise correlations between the two systemic risk measures, managerial risk-taking incentives, and the control variables are presented in Table 2. The negative correlations 
Table 1 Descriptive statistics

\begin{tabular}{|c|c|c|c|c|c|c|c|c|}
\hline Variable & Mean & Median & St.dev. & Min & $\operatorname{Max}$ & P25 & P75 & No. of obs \\
\hline \multicolumn{9}{|l|}{ Dependent variables } \\
\hline $\begin{array}{l}\text { Marginal expected } \\
\text { shortfall (\%) }\end{array}$ & 2.51 & 2.34 & 1.10 & 0.84 & 8.65 & 1.66 & 3.11 & 332 \\
\hline $\begin{array}{l}\text { Systemic risk (\$ } \\
\text { billions) }\end{array}$ & 4.10 & -0.44 & 20.90 & -67.66 & 136.47 & -1.83 & 2.33 & 332 \\
\hline \multicolumn{9}{|c|}{ Managerial risk-taking incentives } \\
\hline $\begin{array}{l}\text { CEO delta ( } \$ \text { thou- } \\
\text { sands) }\end{array}$ & 1642.42 & 526.56 & 4735.40 & 0.69 & $53,121.09$ & 181.33 & 1621.78 & 336 \\
\hline $\begin{array}{l}\text { CEO vega ( } \$ \text { thou- } \\
\text { sands) }\end{array}$ & 320.14 & 154.90 & 476.14 & $1.59 \mathrm{E}-25$ & 3032.25 & 34.79 & 424.24 & 347 \\
\hline $\begin{array}{l}\text { CFO delta (\$ thou- } \\
\text { sands) }\end{array}$ & 403.64 & 61.60 & 3051.02 & 0.05 & $38,202.76$ & 22.48 & 166.82 & 285 \\
\hline $\begin{array}{l}\text { CFO vega (\$ thou- } \\
\text { sands) }\end{array}$ & 80.92 & 31.65 & 135.91 & $7.73 \mathrm{E}-14$ & 859.53 & 9.07 & 94.35 & 285 \\
\hline \multicolumn{9}{|l|}{ Control variables } \\
\hline Size & 257.41 & 57.21 & 481.59 & 0.54 & 3221.97 & 15.94 & 193.32 & 367 \\
\hline Capital ratio & 12.68 & 9.88 & 13.73 & -3.60 & 90.51 & 7.91 & 12.02 & 367 \\
\hline Return on assets & 1.12 & 0.97 & 3.08 & -18.42 & 22.57 & 0.46 & 1.39 & 367 \\
\hline Loans to assets & 50.70 & 60.26 & 24.63 & 0.00 & 90.74 & 34.83 & 69.50 & 338 \\
\hline Loan growth & 14.64 & 6.99 & 58.46 & -72.26 & 704.49 & -1.47 & 17.10 & 310 \\
\hline Deposits to assets & 61.77 & 69.43 & 24.27 & 0.05 & 89.95 & 50.07 & 80.20 & 362 \\
\hline Non-interest income & 49.94 & 43.58 & 31.55 & -76.02 & 175.13 & 30.02 & 74.15 & 367 \\
\hline
\end{tabular}

The table reports the descriptive statistics for the sample. The sample consists of 71 publicly traded U.S. financial institutions. Systemic risk is measured with the following two variables: (1) Marginal expected shortfall $(M E S)$ is the expected daily percentage decrease in equity value of a financial institution when the aggregate stock market falls more than 2\% and (2) Systemic risk (SRISK) is the expected capital shortfall (in $\$$ billions) of a financial institution in a crisis scenario. Managerial Incentives (in $\$$ thousands) are defined as: Delta is the sensitivity of manager's portfolio to stock price and measures the dollar gain or loss in manager's wealth if the firm's stock price changes and Vega is the sensitivity of manager's portfolio to changes in equity volatility. The control variables are defined as follows: Size is measured as the total assets (in \$ billions), Capital ratio is the ratio of equity to total assets, Return on assets is the ratio of net income to total assets, Loans to assets is the ratio of net loans to totals assets, Loan growth is the percentage change in loans from year $t-1$ to year $t$, Deposits to assets is the ratio of deposits to total assets, and Non-interest income is the ratio of non-interest income to total income

between the systemic risk measures and the deltas and vegas of the top executives suggest that financial institutions with greater managerial risk-taking incentives are generally associated with lower levels of systemic risk. The correlations in Table 2 also demonstrate that $M E S$ and SRISK are strongly positively correlated with each other (0.48), and furthermore, that the risk-taking incentives of the CEOs and CFOs are strongly positively correlated. ${ }^{9}$ Given the relatively high correlations between $C E O$ delta and $C F O$ delta (0.45) and especially $C E O$ vega and $C F O$ vega (0.83), we estimate separate regression models for CEO and $\mathrm{CFO}$ risk-taking incentives.

\footnotetext{
${ }^{9}$ We conduct additional tests to ensure that our findings are not affected by the strong correlations between the deltas and vegas.
} 

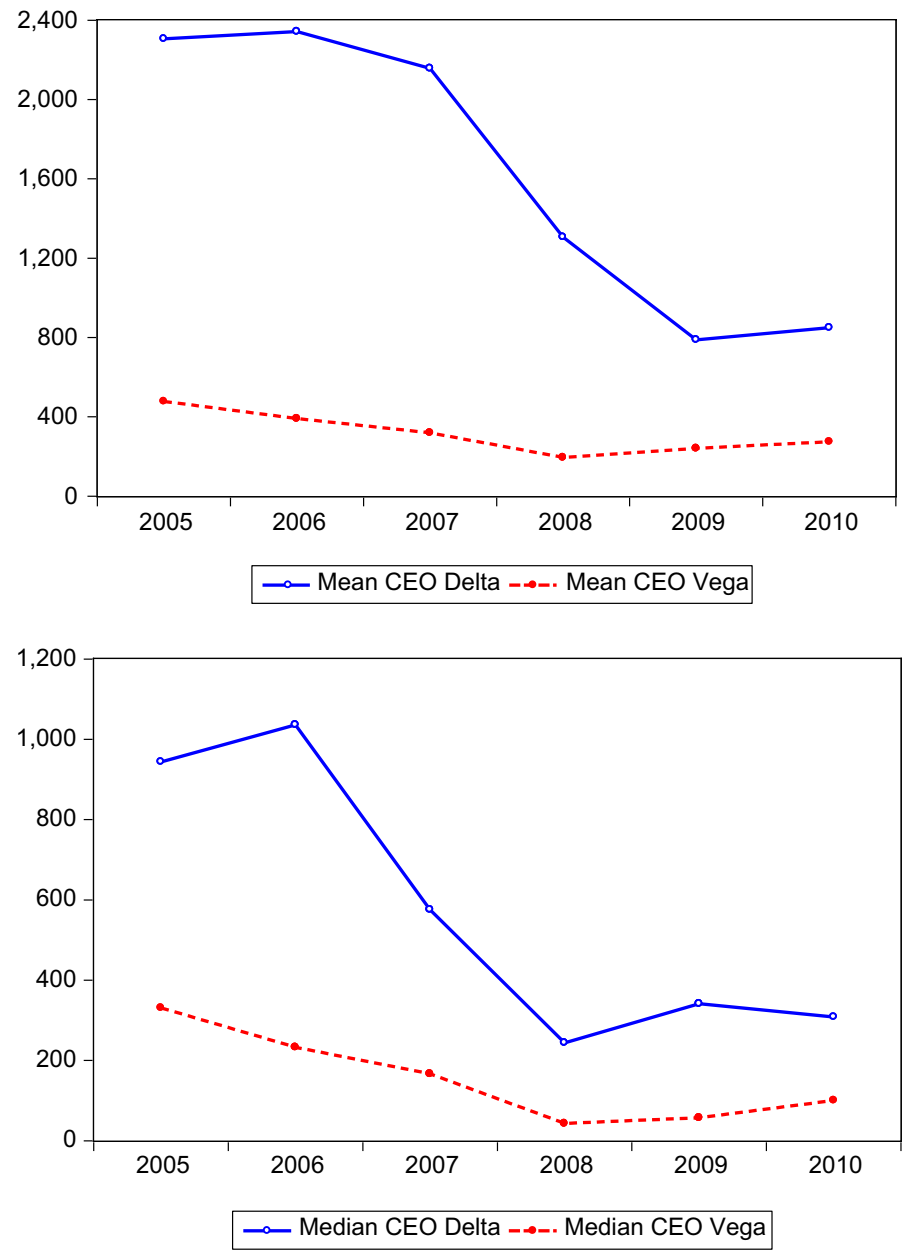

Fig. 1 CEO deltas and vegas. The figures plot the mean and median values of CEO Delta and CEO Vega

With respect to the control variables, it can be noted from Table 2 that the risk-taking incentives of the CEOs and CFOs as well as the two systemic risk measures are positively correlated with the Size. Hence, these correlations indicate that larger financial institutions are associated with higher levels of systemic risk and that the top executives of larger institutions have stronger personal incentives to increase firm-level risk-taking. Our systemic risk measures MES and SRISK also appear to be strongly negatively correlated with Return on assets and Loans to assets. Finally, it is worth noting from Table 2 that several of our control variables are relatively highly correlated with each other. ${ }^{10}$ The strongest correlations observed among the control variables are those between Capital ratio and Return on assets (0.55) and Loans to assets and Non-interest income $(-0.65)$.

\footnotetext{
${ }^{10}$ Given these correlations, we perform several robustness checks to ascertain that our results are not affected by multicollinearity.
} 


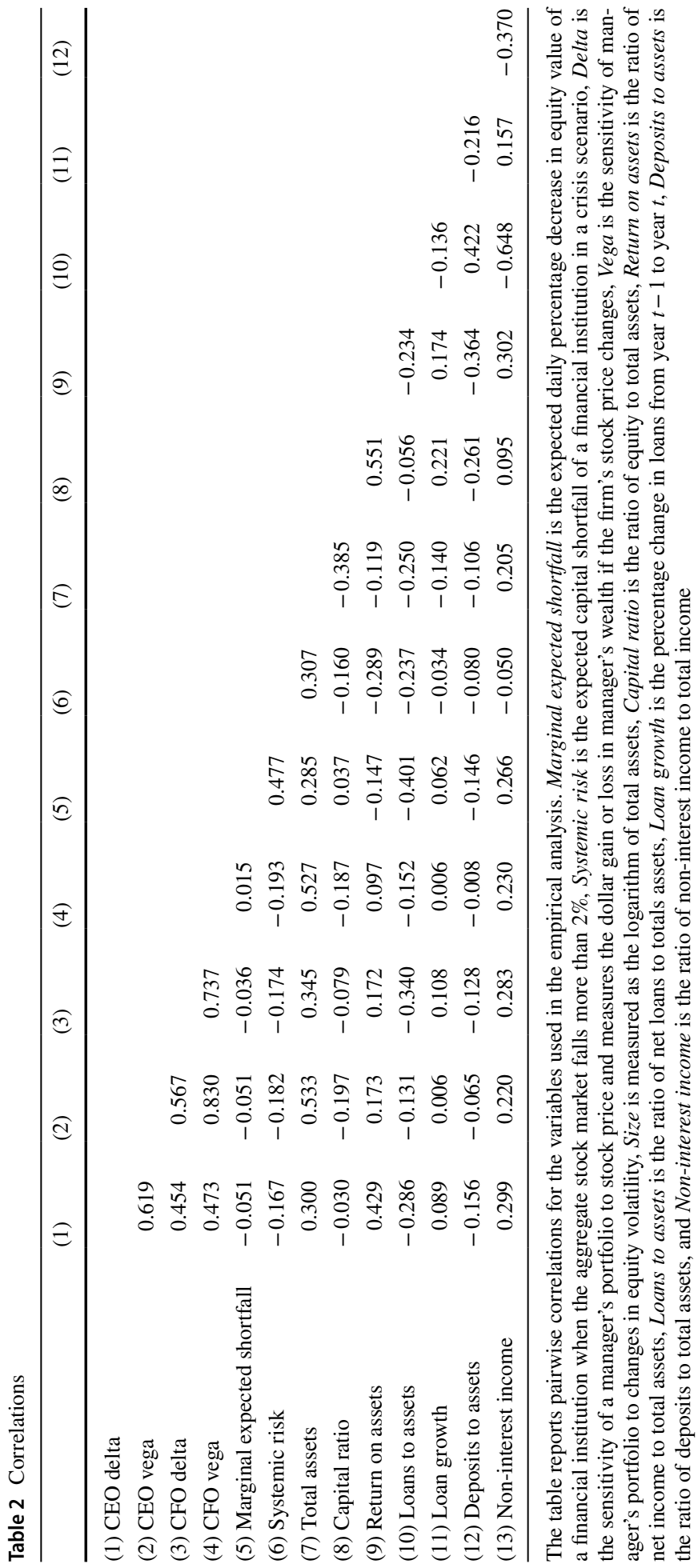


Table 3 Univariate tests

\begin{tabular}{lcccc}
\hline & High systemic risk & Low systemic risk & Difference in means & $t$-stat \\
\hline Risk-taking incentives & & & & -0.19 \\
CEO delta & 6.086 & 6.122 & -0.036 & -1.22 \\
CEO vega & 5.502 & 5.623 & -0.121 & 0.65 \\
CFO delta & 5.326 & 5.269 & 0.057 & -0.22 \\
CFO vega & 5.038 & 5.051 & -0.013 & $3.17^{* * *}$ \\
Control variables & & & 0.657 & $3.71^{* * *}$ \\
Size & 18.155 & 17.499 & 5.950 & 0.65 \\
Capital ratio & 16.078 & 10.129 & 0.231 & $-6.98^{* * *}$ \\
Return on assets & 1.230 & 0.998 & -19.198 & 0.95 \\
Loans to assets & 40.314 & 59.512 & 6.132 & $-4.63^{* * *}$ \\
Loan growth & 15.773 & 9.640 & -4.220 & $7.43^{* * *}$ \\
Depostis to assets & 93.477 & 97.697 & 23.926 & \\
Non-interest income & 61.886 & 37.960 & & \\
\hline
\end{tabular}

The table reports the results of two-tailed $t$-tests under the null hypothesis that there is no difference in the means between financial institutions having higher level of systemic risk and financial institutions having lower level of systemic risk. We divide our sample into two subsamples. The first subsample contains the financial institutions with higher level of systemic risk (financial institutions having systemic risk values in 3rd quartile) and the second subsample contains institutions with lower level of systemic risk (financial institutions having systemic risk values in 1st quartile). Marginal Expected Shortfall is the expected daily decrease in equity value of a financial institution when the aggregate stock market falls more than $2 \%$, Systemic Risk is the expected capital shortfall (measured in billion dollars) of a financial institution in a crisis scenario, Delta is the sensitivity of a manager's portfolio to stock price and measures the dollar gain or loss in manager's wealth if the firm's stock price changes and Vega is the sensitivity of manager's portfolio to changes in equity volatility, Size is measured as the logarithm of total assets, Capital ratio is the ratio of equity to total assets, Return on assets is the ratio of net income to total assets, Loans-to-assets is the ratio of net loans to totals assets, Loan growth is the percentage change in loans from year $t-1$ to year $t$, Deposits to assets is the ratio of deposits to total assets, and Non-interest income is the ratio of non-interest income to total income

$* * *, * *$, and $*$ Significance at the $0.01,0.05$, and 0.10 levels, respectively

\subsection{Univariate tests}

We first examine the relationship between managerial risk-incentives and systemic risk in a univariate setting. For this purpose, we divide the financial institutions into two subsamples based on the level of systemic risk. The first subsample consists of firm-year observations with $M E S$ in the top quartile (high systemic risk) and the second subsample comprises firm-year observations with $M E S$ in the bottom quartile (low systemic risk). Table 3 reports the results of two-tailed $t$-tests with the null hypothesis that there are no differences in the means of the top executive deltas and vegas and the control variables between the high and low systemic risk subsamples. ${ }^{11}$ Interestingly, the $t$-tests indicate that there are no statistically significant differences in the CEO and CFO risk-taking incentives between the financial institutions associated with high and low systemic risk. Thus, in contrast to our

\footnotetext{
11 We also perform the Wilcoxon/Mann-Whitney median tests to examine differences between the high and low systemic risk subsamples. The results are consistent with the $t$-tests reported in Table 3 .
} 
expectations, the univariate tests do not provide support for the view that greater managerial risk-taking incentives would contribute positively to the level of systemic risk.

Regarding the control variables, it can be noted from Table 3 that the high systemic risk institutions are very different from the low systemic risk institutions. Specifically, the univariate tests show that financial institutions associated with higher systemic risk are significantly larger and have higher capital ratios. Moreover, the statistically significant differences between the two subsamples in terms of Loans to assets, Deposits to assets, and Non-interest income suggest that the high systemic risk institutions are more involved in non-traditional banking activities.

\subsection{Regression results}

We examine the association between managerial risk-taking incentives and systemic by estimating alternative versions of the following panel regressions specification:

$$
\begin{aligned}
& \text { Risk }_{i, t}=\alpha+\beta_{1} \text { Delta }_{i, t-1}+\beta_{2} \text { Vega }_{i, t-1}+\beta_{3} \text { Size }_{i, t-1}+\beta_{4} \text { Capital ratio }_{i, t-1} \\
& +\beta_{5} \text { Return on assets }_{i, t-1}+\beta_{6} \text { Loans to assets }_{i, t-1}+\beta_{7}{\text { Loan } \text { growth }_{i, t-1}} \\
& +\beta_{8} \text { Deposits to assets }_{i, t-1}+\beta_{9} \text { Non-interest income }_{i, t-1} \\
& +\sum_{k=1}^{n-1} \alpha_{k} \text { Bank-type }_{i}^{k}+\sum_{y=2006}^{2010} \omega_{y} \text { Year }_{i}^{y}+\varepsilon_{i, t}
\end{aligned}
$$

where the dependent variable Risk $_{i, t}$ is one of the two alternative systemic risk measures for financial institution $i$ at time $t$. The first risk measure is the marginal expected shortfall, MES, calculated as the expected daily decrease in equity value of a financial institution when the aggregate stock market falls more than $2 \%$. The second risk measure is systemic risk, SRISK, defined as the expected capital shortfall of a financial institution in a crisis scenario. Delta and Vega measure the compensation-based risk-taking incentives of the CEOs and CFOs. Delta is the sensitivity of executive compensation to changes in stock price, while Vega is the sensitivity of executive compensation to changes in stock return volatility. In the regressions, we use natural logarithms of MES, SRISK, Delta, and Vega. Given the high correlations between CEO and CFO risk-taking incentives, we do not include the deltas and vegas of the CEOs and CFOs simultaneously in the regressions. In addition to the baseline specification, we also estimate modified versions of Eq. (5) in which we interact the deltas and vegas with a dummy variable for year 2008. With these additional specifications, we aim to assess the potential effects of the financial crisis on the relation between managerial risk-taking incentives and systemic risk.

The control variables in Eq. (5) are defined as follows: Size is measured as the logarithm of total assets, Capital ratio is the ratio of equity to total assets, Return on assets is the ratio of net income to total assets, Loans to assets is the ratio of net loans to totals assets, Loan growth is the percentage change in loans from year $t-1$ to year $t$, Deposits to assets is the ratio of deposits to total assets, and Non-interest income is the ratio of noninterest income to total income. Following the prior literature, all the independent variables are lagged by 1 year. Our regressions include year fixed-effects (Year) to control for time-specific unobservable factors which may influence systemic risk and we also include bank-type fixed-effects (Bank-type) for different types of financial institutions based on SIC codes to control for potentially omitted variables and unobserved heterogeneity. Throughout the regressions, we use robust standard errors which are adjusted for heteroskedasticity 


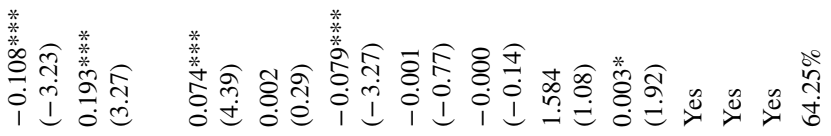

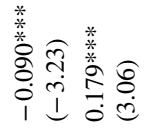

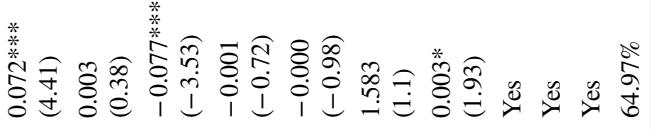

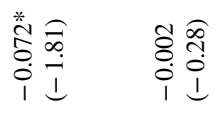

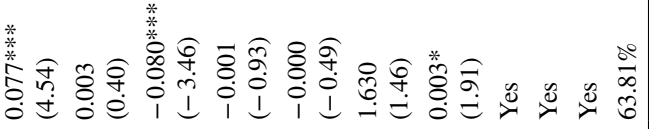

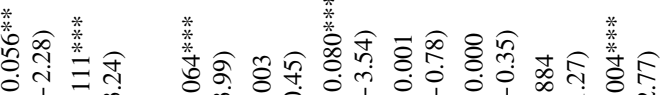

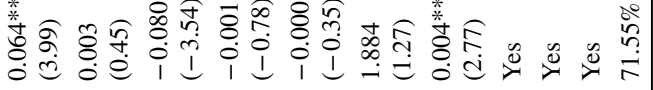

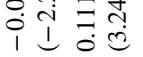

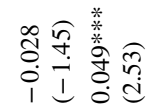

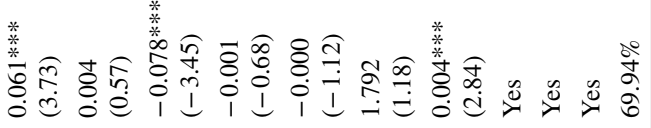

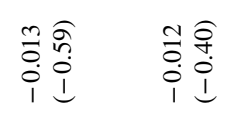

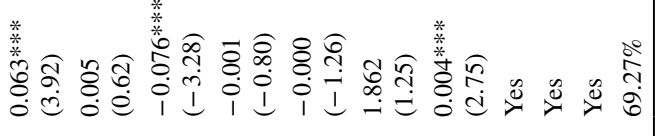

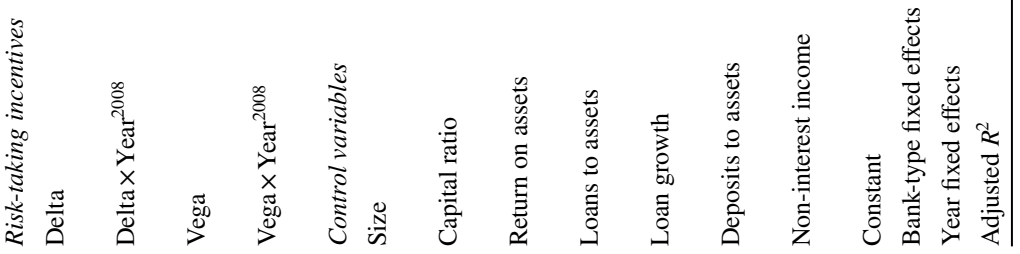




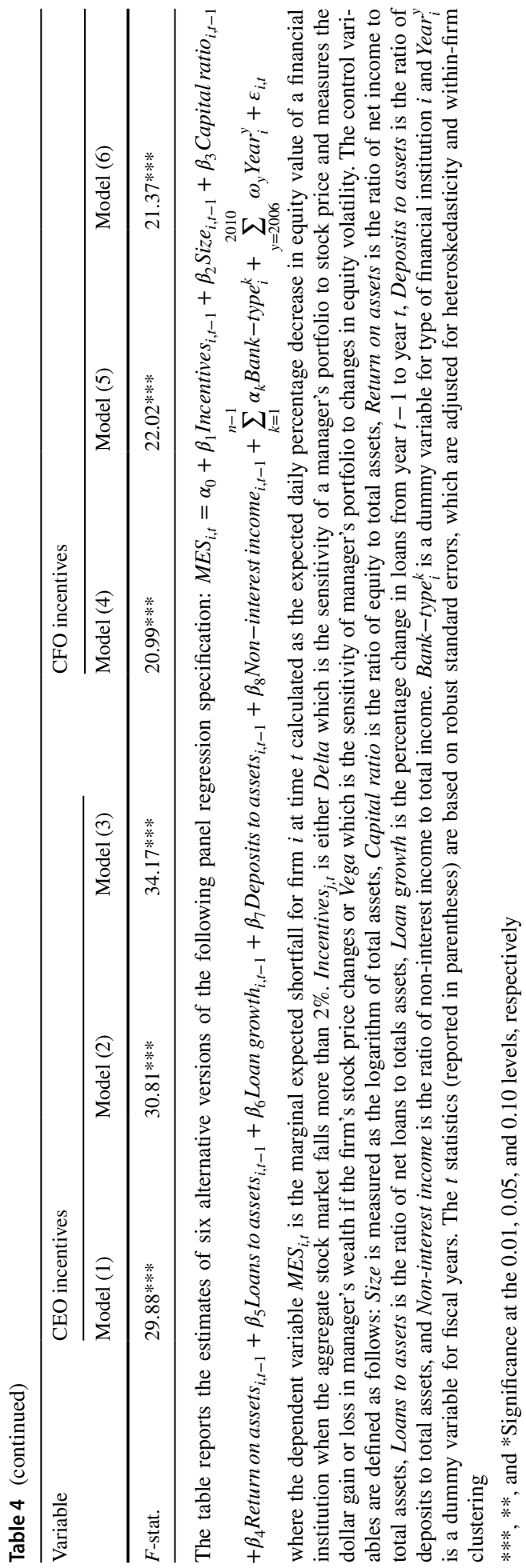


and clustered by firm to account for the potential correlation across observations of the same financial institution over time.

The regression results with marginal expected shortfall, $M E S$, as the dependent variable are reported in Table 4. CEO risk-taking incentives are used as the independent variables of interest in Models 1-3 and CFO incentives in Models 4-6. For both CEO and CFO risk-taking incentives, we first estimate the regressions by including Delta and Vega in the same regression with all of the control variables (Models 1 and 4). We then estimate four alternative interaction specifications in which the CEO and CFO deltas are interacted with a dummy variable for the crisis year 2008 (Models 2 and 5) and in which the CEO and $\mathrm{CFO}$ vegas are interacted with the same dummy (Models 3 and 6). As can be seen from Table 4, the adjusted $R^{2}$ s of our alternative regression specifications vary between 64 and $72 \%$ and the $F$-statistics are all statistically significant at the $1 \%$ level, indicating a good fit of the models. ${ }^{12}$

The main variables of interest in our regressions are Delta and Vega and the two interaction variables Delta $\times Y_{e a r^{2008}}$ and Vega $\times Y_{\text {Year }}^{2008}$. As can be noted from Table 4, the coefficient estimates for $C E O$ delta and CEO vega in Model 1 are statistically insignificant, suggesting that $M E S$ is not affected by CEO risk-taking incentives. However, after the inclusion of the crisis interactions in Models 2 and 3, the coefficient estimate for CEO vega is negative and statistically significant and the coefficients for the both interaction variables CEO delta $\times$ Year $^{2008}$ and CEO vega $\times$ Year $^{2008}$ are positive and highly significant. Accordingly, our estimates indicate that financial institutions led by CEOs with greater compensation-based risk-taking incentives were associated with significantly higher $M E S$ in the midst of the global financial crisis in 2008.

In Models 4-6 with CFO risk-taking incentives as the variables of interest, the coefficients for $C F O$ delta are negative and statistically significant, suggesting that $M E S$ is lower for institutions with greater CFO pay-performance sensitivity. This finding is inconsistent with the view that compensation-based managerial incentives encourage greater risktaking. Nevertheless, similar to the CEO incentive regressions, the coefficient estimates for both interaction variables CFO delta $\times$ Year $^{2008}$ and CFO vega $\times$ Year $^{2008}$ are positive and statistically significant at the $1 \%$ level in Models 5 and 6 . Since delta and vega are proxies of managerial risk-taking incentives, the interaction regressions in Table 4 suggest that financial institutions with greater compensation-based risk-taking incentives of the top executives at the onset of the financial crisis were associated with higher levels of systemic risk during the severe financial market turmoil in 2008.

In addition to being statistically significant, the coefficients for the interaction variables in Table 4 can also be considered economically significant. The coefficient estimate for $C E O$ delta $\times$ Year $^{2008}$ in Model 2 suggests that a one standard deviation increase in the precrisis $C E O$ delta would be associated with a 30 basis point increase in $M E S$ in the year 2008. Similarly, the magnitudes of the statistically significant coefficients for CEO vega and $C E O$ vega $\times$ Year $^{2008}$ in Model 3 jointly imply that a one standard deviation increase in pre-crisis vega of the CEO increases $M E S$ by approximately 40 basis points during the financial crisis. Consistent with Models 2 and 3, the estimates for the CFO risk-taking incentives in Models 5 and 6 indicate that one standard deviation increases in $C F O$ delta and $C F O$ vega are associated with about 25 basis point increase in $M E S$ amidst the crisis. Given that the average book value of equity for the financial institutions in our sample is

\footnotetext{
12 The adjusted $R^{2}$ is $26 \%$ when only the control variables are used as the independent variables. After the inclusion of bank-type and year fixed-effects, the adjusted $R^{2}$ is about $58 \%$.
} 
Table 5 Managerial risk-taking incentives and systemic risk (SRISK)

\begin{tabular}{|c|c|c|c|c|c|c|}
\hline \multirow[t]{2}{*}{ Variable } & \multicolumn{3}{|c|}{ CEO incentives } & \multicolumn{3}{|c|}{ CFO incentives } \\
\hline & Model (1) & Model (2) & Model (3) & Model (4) & Model (5) & Model (6) \\
\hline \multicolumn{7}{|l|}{ Risk-taking incentives } \\
\hline Delta & $\begin{array}{l}0.002 \\
(0.16)\end{array}$ & $\begin{array}{l}-0.028 * * * \\
(-2.98)\end{array}$ & & $\begin{array}{l}0.011 \\
(0.53)\end{array}$ & $\begin{array}{l}-0.067 * * \\
(-2.25)\end{array}$ & \\
\hline Delta $\times$ Year $^{2008}$ & & $\begin{array}{l}0.035 * * * \\
(2.55)\end{array}$ & & & $\begin{array}{l}0.128 * * * \\
(2.49)\end{array}$ & \\
\hline Vega & $\begin{array}{l}-0.072 * * * \\
(-2.54)\end{array}$ & & $\begin{array}{l}-0.098 * * * \\
(-3.33)\end{array}$ & $\begin{array}{l}-0.124 * * * \\
(-2.66)\end{array}$ & & $\begin{array}{l}-0.144 * * * \\
(-4.06)\end{array}$ \\
\hline Vega $\times$ Year $^{2008}$ & & & $\begin{array}{l}0.107 * * * \\
(2.51)\end{array}$ & & & $\begin{array}{l}0.171^{* *} \\
(2.45)\end{array}$ \\
\hline \multicolumn{7}{|l|}{ Control variables } \\
\hline Size & $\begin{array}{l}0.060 * * * \\
(4.67)\end{array}$ & $\begin{array}{l}0.045 * * * \\
(3.46)\end{array}$ & $\begin{array}{l}0.061 * * * \\
(5.02)\end{array}$ & $\begin{array}{l}0.080 * * * \\
(4.87)\end{array}$ & $\begin{array}{l}0.067 * * * \\
(4.16)\end{array}$ & $\begin{array}{l}0.077 * * * \\
(4.84)\end{array}$ \\
\hline Capital ratio & $\begin{array}{l}-0.001 \\
(-0.15)\end{array}$ & $\begin{array}{l}-0.002 \\
(-0.51)\end{array}$ & $\begin{array}{l}-0.002 \\
(-0.59)\end{array}$ & $\begin{array}{l}0.003 \\
(0.52)\end{array}$ & $\begin{array}{l}0.003 \\
(0.53)\end{array}$ & $\begin{array}{l}0.002 \\
(0.46)\end{array}$ \\
\hline Return on assets & $\begin{array}{l}-0.020^{*} \\
(-1.80)\end{array}$ & $\begin{array}{l}-0.024^{*} \\
(-1.75)\end{array}$ & $\begin{array}{l}-0.020 * \\
(-1.63)\end{array}$ & $\begin{array}{l}-0.014 \\
(-1.17)\end{array}$ & $\begin{array}{l}-0.017 \\
(-1.19)\end{array}$ & $\begin{array}{l}-0.012 \\
(-0.99)\end{array}$ \\
\hline Loans to assets & $\begin{array}{l}-0.001^{*} \\
(-1.66)\end{array}$ & $\begin{array}{l}-0.002^{*} \\
(-1.63)\end{array}$ & $\begin{array}{l}-0.002 * \\
(-1.68)\end{array}$ & $\begin{array}{l}-0.002 * \\
(-1.90)\end{array}$ & $\begin{array}{l}-0.002 * \\
(-1.82)\end{array}$ & $\begin{array}{l}-0.002 * \\
(-1.91)\end{array}$ \\
\hline Loan growth & $\begin{array}{l}0.000 \\
(-0.87)\end{array}$ & $\begin{array}{l}0.000 \\
(0.93)\end{array}$ & $\begin{array}{l}0.000 * \\
(1.80)\end{array}$ & $\begin{array}{l}0.000 \\
(1.20)\end{array}$ & $\begin{array}{l}0.000 \\
(0.72)\end{array}$ & $\begin{array}{l}0.000 * \\
(1.81)\end{array}$ \\
\hline Deposits to assets & $\begin{array}{l}0.253 \\
(0.54)\end{array}$ & $\begin{array}{l}0.152 \\
(0.38)\end{array}$ & $\begin{array}{l}0.405 \\
(0.81)\end{array}$ & $\begin{array}{l}1.059 \\
(1.40)\end{array}$ & $\begin{array}{l}0.974 \\
(1.24)\end{array}$ & $\begin{array}{l}1.106 \\
(1.42)\end{array}$ \\
\hline Non-interest income & $\begin{array}{l}-0.001 * * \\
(-2.28)\end{array}$ & $\begin{array}{l}-0.002^{* * * *} \\
(-2.61)\end{array}$ & $\begin{array}{l}-0.001 * * \\
(-2.19)\end{array}$ & $\begin{array}{l}-0.002 * * * \\
(-2.60)\end{array}$ & $\begin{array}{l}-0.002 * * * \\
(-2.65)\end{array}$ & $\begin{array}{l}-0.002 * * * \\
(-2.58)\end{array}$ \\
\hline Constant & Yes & Yes & Yes & Yes & Yes & Yes \\
\hline Bank-type fixed effects & Yes & Yes & Yes & Yes & Yes & Yes \\
\hline Year fixed effects & Yes & Yes & Yes & Yes & Yes & Yes \\
\hline Adjusted $R^{2}$ & $33.54 \%$ & $30.54 \%$ & $41.02 \%$ & $53.49 \%$ & $52.24 \%$ & $56.82 \%$ \\
\hline$F$-stat. & $7.47 * * *$ & $6.63 * * *$ & $10.17 * * *$ & $14.03 * * *$ & $13.4 * * *$ & $15.91 * * *$ \\
\hline
\end{tabular}

The table reports the estimates of six alternative versions of the following panel regression specification: $\quad \operatorname{SRISK}_{i, t}=\alpha_{0}+\beta_{1}$ Incentives $_{i, t-1}+\beta_{2}$ Size $_{i, t-1}+\beta_{3}$ Capital ratio $_{i, t-1}+\beta_{4}$ Return on assets $_{i, t-1}$ $+\beta_{5}$ Loans to assets $_{i, t-1}+\beta_{6}$ Loan growth $_{i, t-1}+\beta_{7}$ Deposits to assets $_{i, t-1}+\beta_{8}$ Non-interest income $_{i, t-1}+\sum_{k=1}^{n-1} \alpha_{k}$ Bank-type $_{i}^{k}+\sum_{y=2006}^{2010} \omega_{y}$ Year $_{i}^{y}+\varepsilon_{i, t}$

where the dependent variable $\operatorname{SRISK}_{i, t}$ is the systemic risk for firm $i$ at time $t$ calculated as the is the expected capital shortfall in a crisis scenario. Incentives ${ }_{j, t}$ is either the Delta which is the sensitivity of a manager's portfolio to stock price and measures the dollar gain or loss in manager's wealth if the firm's stock price changes or Vega which is the sensitivity of manager's portfolio to changes in equity volatility. The control variables are defined as follows: Size is measured as the logarithm of total assets, Capital ratio is the ratio of equity to total assets, Return on assets is the ratio of net income to total assets, Loans to assets is the ratio of net loans to totals assets, Loan growth is the percentage change in loans from year $t-1$ to year $t$, Deposits to assets is the ratio of deposits to total assets, and Non-interest income is the ratio of noninterest income to total income. Bank-type ${ }_{i}^{k}$ is a dummy variable for type of financial institution $i$ and $Y_{e a r_{i}^{y}}^{y}$ is a dummy variable for fiscal years. The $t$-statistics (reported in parentheses) are based on robust standard errors which are adjusted for heteroskedasticity and within-firm clustering

$* * *, * *$, and $*$ Significance at the $0.01,0.05$, and 0.10 levels, respectively 
about USD 16 billion, these 25-40 basis point increases in $M E S$ are economically highly significant.

With respect to the control variables, the regression results in Table 4 show that systemic risk as measured by $M E S$ is statistically significantly positively associated with Size and Non-interest income and negatively associated with Return on assets. Thus, our estimates suggest that larger financial institutions which are more involved in non-traditional banking activities and institutions with weaker financial performance are associated with higher levels of systemic risk.

Table 5 reports the regression results with systemic risk, SRISK, as the dependent variable. Similar to Table 4, CEO risk-taking incentives are used as the independent variables of interest in Models 1-3, while CFO incentives are used in Models 4-6. As can be noted from Table 5, the $F$-statistics for all six model specifications are statistically significant at the $1 \%$ level and the adjusted $R^{2}$ s of the estimated regressions range from 31 to $57 \%$.

Overall, the estimates of the SRISK regressions in Table 5 are very similar to the MES regressions reported in Table 4 . The most notable differences between the two sets of results are the statistically significant coefficients for $C E O$ vega in Model 1 and $C F O$ vega in Model 4. These negative and highly significant coefficients indicate that financial institutions with greater risk-sensitivities of the top executives are generally associated with lower levels of systemic risk. The coefficient estimates indicate that a $10 \%$ increase in CEO vega would decrease SRISK by $0.7 \%$, while a corresponding increase in $C F O$ vega is associated with a $1.2 \%$ decrease in SRISK. Furthermore, one standard deviation increases in $C E O$ vega and CFO vega would decrease SRISK by approximately 6.0\%. The average SRISK for the institutions included in our sample is about USD 4.1 billion, and therefore, these reductions in SRISK can be considered economically significant. The documented negative linkage between CEO and CFO vegas and SRISK contrasts with the hypothesis that higher managerial risk-taking incentives would contribute positively to the level of systemic risk. Consistent with the agency theory (Jensen and Meckling 1976), this negative association between vegas and systemic risk may suggest that the top executives of financial institutions tend to be risk averse.

Similar to Table 4, the coefficient estimates for the interaction variables Delta $\times$ Year $^{2008}$ and Vega $\times$ Year $^{2008}$ are positive and statistically significant at the $1 \%$ level in all four interaction regressions. Thus, consistent with our MES regressions, the regressions in Table 5 suggest that financial institutions with greater risk-taking incentives of the top executives prior the financial crisis were associated with higher levels of systemic risk during the crisis. Nevertheless, the magnitudes of the coefficients indicate that the positive association between managerial risk-taking incentives and SRISK in the midst of the financial crisis is rather marginal. The estimates of Models 2 and 3 imply that a $10 \%$ increase in precrisis CEO delta and CEO vega would increase SRISK by less than $0.10 \%$ during the financial crisis. With respect to CFO incentives, the estimates of Model 5 and 6 suggest that $10 \%$ increases (one standard deviation increases) in pre-crisis $C F O$ delta and $C F O$ vega are associated with $0.6 \%(4.7 \%)$ and $0.3 \%(1.4 \%)$ increases in SRISK, respectively. With average SRISK of about USD 4.1 billion, these increases in SRISK during the crisis can be considered economically significant.

The coefficient estimates for the control variables in Table 5 indicate that systemic risk is significantly negatively related to Return on assets, Loans to assets, and Non-interest income, while being positively associated with Size. This suggests that systemically more risky financial institutions are larger and have lower profitability, lower amounts of outstanding loans, and less income diversification. 
In general, the regression results reported in Tables 4 and 5 provide mixed evidence about the linkage between top executive risk-taking incentives and the systemic risk of financial institutions. Specifically, our findings indicate that the relationship between managerial risk-taking incentives and banks' systemic risk is not stable over time. On the one hand, our results indicate that the sensitivities of CEO and CFO compensation to stock return volatility are negatively associated with the systemic risk of financial institutions over our sample period 2005-2010. This finding is in stark contrast with the hypothesis that higher managerial risk-taking incentives would increase the level of systemic risk. Nevertheless, the documented negative association between vegas and banks' systemic risk is consistent with the less recognized alternative view that compensation-based risk-taking incentives may induce risk-averse executives to adopt less risky policies (e.g., Carpenter 2000; Meulbroek 2001; Ross 2004; Hayes et al. 2012). On the other hand, our regressions also demonstrate that financial institutions with greater managerial risk-taking incentives were associated with significantly higher levels of MES and SRISK in the midst of the global financial crisis in 2008. Taken as a whole, the regressions in Tables 4 and 5 together with the univariate tests in Table 3 do not generally provide support for the view that the risk-taking incentives of the top executives contribute positively to the level of systemic risk.

\subsection{Additional tests}

We perform several additional tests to investigate the robustness of our findings. Given that managerial risk-aversion may obviously influence the relation between CEO and CFO vegas and systemic risk, we first aim to control for the level of executive risk aversion. Following Guay (1999), Coles et al. (2006), DeYoung et al. (2013), and Croci and Petmezas (2015), we use executives' cash compensation as a proxy for managerial risk-aversion. The prior studies posit that executives with higher total cash compensation are less risk averse. Thus, we estimate regressions with the logarithm of the sum of executive salaries and cash bonuses as an additional control variable. The estimates of these regressions are reported in Table 6. Consistent with our main results, the coefficient estimates for CEO vega and $C F O$ vega are negative and statistically highly significant in 10 out of 12 alternative specifications, and the coefficients for the interaction variables Vega $\times$ Year $^{2008}$ are positive and statistically significant in all four interaction regressions. Thus, we conclude that our main findings are robust to the inclusion of a proxy for managerial risk-aversion. The estimated coefficients for CFO cash compensation are positive and statistically significant in the regressions with SRISK as the dependent variable, suggesting that institutions with higher $\mathrm{CFO}$ cash compensation are associated with greater risk-taking.

Second, we acknowledge that SRISK is dominated by the size of the institution, and moreover, that our managerial risk-taking incentive variables are strongly positively correlated with institution size. To further examine the robustness of our findings, we scale SRISK by total assets and re-estimate the regressions tabulated in Table 5 with SRISK as the dependent variable. The results of these additional regressions are reported in Table 7. As can be noted from the table, the coefficient estimates for CEO vega and CFO vega are negative and statistically significant. Nevertheless, in contrast to our main SRISK regressions reported in Table 5, the coefficients for the interaction variables Delta $\times Y_{\text {Year }}{ }^{2008}$ and $V e g a \times Y_{e a r}^{2008}$ are insignificant with the only exception being the positive coefficient estimate for CEO vega $\times$ Year $^{2008}$ in Model 3. Overall, the additional regressions in Table 7 
Table 6 Managerial risk-taking incentives, managerial risk-aversion, and systemic risk

\begin{tabular}{|c|c|c|c|c|c|c|}
\hline \multirow[t]{2}{*}{ Variable } & \multicolumn{3}{|c|}{ CEO incentives } & \multicolumn{3}{|c|}{ CFO incentives } \\
\hline & Model (1) & Model (2) & Model (3) & Model (4) & Model (5) & Model (6) \\
\hline \multicolumn{7}{|c|}{ Panel A: Marginal expected shortfall (MES) regressions } \\
\hline Delta & $\begin{array}{l}-0.013 * \\
(-1.72)\end{array}$ & & & $\begin{array}{l}-0.072 * * \\
(-2.10)\end{array}$ & & \\
\hline Vega & $\begin{array}{l}-0.018 \\
(-1.14)\end{array}$ & $\begin{array}{l}-0.039 * * * \\
(-2.97)\end{array}$ & $\begin{array}{l}-0.060 * * \\
(-2.55)\end{array}$ & $\begin{array}{l}-0.009 \\
(-0.14)\end{array}$ & $\begin{array}{l}-0.082 * * \\
(-2.15)\end{array}$ & $\begin{array}{l}-0.118 * * \\
(-2.11)\end{array}$ \\
\hline Vega $\times$ Year $^{2008}$ & & & $\begin{array}{l}0.109 * * * \\
(5.20)\end{array}$ & & & $\begin{array}{l}0.201 * * * \\
(5.97)\end{array}$ \\
\hline $\begin{array}{l}\text { Managerial risk- } \\
\text { aversion }\end{array}$ & $\begin{array}{l}-0.018 \\
(-1.48)\end{array}$ & $\begin{array}{l}-0.014 \\
(-1.01)\end{array}$ & $\begin{array}{l}-0.013 \\
(-0.92)\end{array}$ & $\begin{array}{l}0.039 \\
(1.11)\end{array}$ & $\begin{array}{l}0.039 \\
(1.13)\end{array}$ & $\begin{array}{l}0.044 \\
(1.14)\end{array}$ \\
\hline Constant & Yes & Yes & Yes & Yes & Yes & Yes \\
\hline Control variables & Yes & Yes & Yes & Yes & Yes & Yes \\
\hline Bank-type fixed effects & Yes & Yes & Yes & Yes & Yes & Yes \\
\hline Year fixed effects & Yes & Yes & Yes & Yes & Yes & Yes \\
\hline Adjusted $R^{2}$ & $72.00 \%$ & $73.06 \%$ & $73.87 \%$ & $67.29 \%$ & $66.76 \%$ & $67.76 \%$ \\
\hline$F$-stat. & $28.43 * * *$ & $33.05 * * *$ & $32.27 * * *$ & $19.8 * * *$ & $20.76 * * *$ & $20.23 * * *$ \\
\hline \multicolumn{7}{|c|}{ Panel B: Systemic risk (SRISK) regressions } \\
\hline Delta & $\begin{array}{l}0.002 \\
(0.51)\end{array}$ & & & $\begin{array}{l}0.010 \\
(0.58)\end{array}$ & & \\
\hline Vega & $\begin{array}{l}-0.078 * * * \\
(-4.06)\end{array}$ & $\begin{array}{l}-0.083^{* * *} \\
(-5.48)\end{array}$ & $\begin{array}{l}-0.103 * * * \\
(-6.29)\end{array}$ & $\begin{array}{l}-0.134 * * * \\
(-11.21)\end{array}$ & $\begin{array}{l}-0.124 * * * \\
(-5.73)\end{array}$ & $\begin{array}{l}-0.157 * * * \\
(-10.29)\end{array}$ \\
\hline Vega $\times$ Year $^{2008}$ & & & $\begin{array}{l}0.104^{* * * *} \\
(3.92)\end{array}$ & & & $\begin{array}{l}0.182 * * * \\
(16.26)\end{array}$ \\
\hline $\begin{array}{l}\text { Managerial risk- } \\
\text { aversion }\end{array}$ & $\begin{array}{l}-0.019 \\
(-0.91)\end{array}$ & $\begin{array}{l}-0.016 \\
(-0.76)\end{array}$ & $\begin{array}{l}-0.015 \\
(-0.70)\end{array}$ & $\begin{array}{l}0.053 * * \\
(2.38)\end{array}$ & $\begin{array}{l}0.053 * * \\
(2.28)\end{array}$ & $\begin{array}{l}0.058 * * \\
(2.32)\end{array}$ \\
\hline Constant & Yes & Yes & Yes & Yes & Yes & Yes \\
\hline Control variables & Yes & Yes & Yes & Yes & Yes & Yes \\
\hline Bank-type fixed effects & Yes & Yes & Yes & Yes & Yes & Yes \\
\hline Year fixed effects & Yes & Yes & Yes & Yes & Yes & Yes \\
\hline Adjusted $R^{2}$ & $40.10 \%$ & $43.44 \%$ & $46.28 \%$ & $59.79 \%$ & $59.74 \%$ & $63.19 \%$ \\
\hline$F$-stat. & $7.4 * * *$ & $9.36 * * *$ & $9.83 * * *$ & $14.31 * * *$ & $15.33 * * *$ & $16.52 * * *$ \\
\hline
\end{tabular}

The table reports the estimates of six alternative regressions. In Panel A, the dependent variable is the marginal expected shortfall $\left(M E S_{i, t}\right)$ for firm $i$ at time $t$ calculated as the expected daily percentage decrease in equity value of a financial institution when the aggregate stock market falls more than $2 \%$. In Panel B, the dependent variable is the systemic risk $\left(S R I S K_{i, t}\right)$ for firm $i$ at time $t$ calculated as the is the expected capital shortfall in a crisis scenario. Managerial risk-taking incentives are measured with Delta which is the sensitivity of a manager's portfolio to stock price and measures the dollar gain or loss in manager's wealth if the firm's stock price changes and Vega which is the sensitivity of manager's portfolio to changes in equity volatility. Managerial risk-aversion is proxied by executives' cash compensation. The control variables are defined as follows: Size is measured as the logarithm of total assets, Capital ratio is the ratio of equity to total assets, Return on assets is the ratio of net income to total assets, Loans to assets is the ratio of net loans to totals assets, Loan growth is the percentage change in loans from year $t-1$ to year $t$, Deposits to assets is the ratio of deposits to total assets, and Non-interest income is the ratio of non-interest income to total income. Bank - type ${ }_{i}^{k}$ is a dummy variable for type of financial institution $i$ and Year ${ }_{i}^{y}$ is a dummy variable for fiscal years. The $t$-statistics (reported in parentheses) are based on robust standard errors which are adjusted for heteroskedasticity and within-firm clustering $* * *, * *$, and $*$ Significance at the $0.01,0.05$, and 0.10 levels, respectively 
Table 7 Managerial risk-taking incentives and systemic risk (SRISK) scaled by total assets

\begin{tabular}{|c|c|c|c|c|c|c|}
\hline \multirow[t]{2}{*}{ Variable } & \multicolumn{3}{|c|}{ CEO incentives } & \multicolumn{3}{|c|}{ CFO incentives } \\
\hline & Model (1) & Model (2) & Model (3) & Model (4) & Model (5) & Model (6) \\
\hline Delta & $\begin{array}{l}0.001 \\
(0.73)\end{array}$ & $\begin{array}{l}-0.002 * * * \\
(-3.13)\end{array}$ & & $\begin{array}{l}0.006^{*} \\
(1.84)\end{array}$ & $\begin{array}{l}-0.005 \\
(-1.17)\end{array}$ & \\
\hline Delta $\times$ Year $^{2008}$ & & $\begin{array}{l}0.001 \\
(0.09)\end{array}$ & & & $\begin{array}{l}-0.008 \\
(-1.26)\end{array}$ & \\
\hline Vega & $\begin{array}{l}-0.010^{*} \\
(-1.95)\end{array}$ & & $\begin{array}{l}-0.009 * * \\
(-2.20)\end{array}$ & $\begin{array}{l}-0.023 * * \\
(-2.29)\end{array}$ & & $\begin{array}{l}-0.016^{* *} \\
(-2.21)\end{array}$ \\
\hline Vega $\times$ Year $^{2008}$ & & & $\begin{array}{l}0.001 * \\
(1.90)\end{array}$ & & & $\begin{array}{l}-0.003 \\
(-1.23)\end{array}$ \\
\hline Constant & Yes & Yes & Yes & Yes & Yes & Yes \\
\hline Control variables & Yes & Yes & Yes & Yes & Yes & Yes \\
\hline Bank-type fixed effects & Yes & Yes & Yes & Yes & Yes & Yes \\
\hline Year fixed effects & Yes & Yes & Yes & Yes & Yes & Yes \\
\hline Adjusted $R^{2}$ & $35.74 \%$ & $29.74 \%$ & $30.07 \%$ & $39.78 \%$ & $34.19 \%$ & $39.09 \%$ \\
\hline$F$-stat. & $6.5 * * *$ & $4.95 * * *$ & $6.61 * * *$ & $6.74 * * *$ & $5.3 * * *$ & $6.55 * * *$ \\
\hline
\end{tabular}

The table reports the estimates of six alternative regressions with systemic risk (SRISK) scaled by total assets as the dependent variable. SRISK $K_{i, t}$ for firm $i$ at time $t$ calculated as the is the expected capital shortfall in a crisis scenario. Managerial risk-taking incentives are measured with Delta which is the sensitivity of a manager's portfolio to stock price and measures the dollar gain or loss in manager's wealth if the firm's stock price changes and Vega which is the sensitivity of manager's portfolio to changes in equity volatility. The control variables are defined as follows: Size is measured as the logarithm of total assets, Capital ratio is the ratio of equity to total assets, Return on assets is the ratio of net income to total assets, Loans to assets is the ratio of net loans to totals assets, Loan growth is the percentage change in loans from year $t-1$ to year $t$, Deposits to assets is the ratio of deposits to total assets, and Non-interest income is the ratio of non-interest income to total income. Bank - type ${ }_{i}^{k}$ is a dummy variable for type of financial institution $i$ and Year $_{i}^{y}$ is a dummy variable for fiscal years. The $t$-statistics (reported in parentheses) are based on robust standard errors which are adjusted for heteroskedasticity and within-firm clustering

$* * *, * *$, and $*$ Significance at the $0.01,0.05$, and 0.10 levels, respectively

provide further evidence that the sensitivities of CEO and CFO compensation to stock return volatility are negatively associated with systemic risk.

Third, in order to ensure that the high correlations between the managerial risk-taking incentive variables do not affect our results, we re-estimate Models 1 and 4 in Tables 4 and 5 using only one incentive variable at a time (results not tabulated). Similar to Model 1 in Table 4, the coefficients for CEO delta and CEO vega with $M E S$ as the dependent variable are statistically insignificant even when these variables are not used simultaneously in the regression. In contrast to our main analysis, the coefficient estimates for $C F O$ delta and $C F O$ vega are negative and statistically significant in the $M E S$ regressions (Model 4 in Table 4) and the coefficients for $C E O$ delta and $C F O$ delta are negative and significant at the $1 \%$ level in the SRISK regressions (Models 1 and 4 in Table 5). The coefficients for $C E O$ vega and $C F O$ vega in the regressions with SRISK as the dependent variable are negative and highly significant consistent with Models 1 and 4 in Table 5. Thus, these additional regressions strongly suggest that financial institutions with greater compensationbased managerial risk-taking incentives are generally associated with lower systemic risk.

Fourth, despite the severe multicollinearity concerns, we also experiment by estimating regressions in which we simultaneously use the deltas and vegas and their respective 
interactions with the crisis year 2008 dummy variable. The estimates of these regressions (not tabulated) are very similar to the interaction regressions reported in Tables 4 and 5. Specifically, the coefficients for CEO vega are negative and statistically highly significant both in the MES and SRISK regressions, and the coefficient for CFO vega is negative and significant at the $1 \%$ level in the regression with SRISK as the dependent variable. Consistent with our main analysis, the coefficient estimates for CEO vega $\times$ Year $^{2008}$ and $C F O$ vega $\times$ Year $^{2008}$ are positive and highly significant throughout the alternative regression specifications. The coefficient estimates for CEO delta and $C E O$ delta $\times Y_{\text {Year }}^{2008}$ are insignificant, while the coefficient for $C F O$ delta is negative and the coefficient for $C F O$ delta $\times$ Year ${ }^{2008}$ positive in the regression with $M E S$ as the dependent variable.

Fifth, following Fahlenbrach and Stulz (2011), we re-estimate all our regression specifications by using the sums of CEO and CFO deltas and CEO and CFO vegas as the incentive variables. Fahlenbrach and Stulz (2011) use the combined incentives of the top five highest-paid executives, whereas we only combine the deltas and vegas of the CEOs and CFOs. The estimates of these additional regressions (not tabulated) are very similar to the estimates reported in Table 4 and 5. The coefficients for the combined deltas and vegas as well as for the interaction variables have the same signs and also largely the same significance levels as in our main analysis.

Sixth, we winsorize all the variables at the 2.5th and 97.5th percentiles to examine whether our findings are affected by outliers or extreme observations. When the regressions are re-estimated with the winsorized variables (not tabulated), the coefficients for the risk-taking incentive variables remain virtually unchanged. Once again, the estimates indicate that $C E O$ vega and $C F O$ vega are significantly negatively associated with SRISK, and the positive and significant coefficients for the interaction variables demonstrate that financial institutions with greater managerial risk-taking incentives in 2007 were associated with higher MES and SRISK amidst the financial crisis in 2008. We therefore conclude that our empirical findings are not driven by outliers.

Seventh, we re-estimate the regressions by using firm fixed-effects instead of bank-type fixed-effects to control for omitted variables and unobserved heterogeneity. The estimation results with firm fixed-effects (not tabulated) are broadly consistent with our main regressions. Specifically, the coefficient estimates for the interaction variables Delta $\times Y_{\text {ear }}{ }^{2008}$ and Vega $\times$ Year $^{2008}$ are always positive and statistically significant, and therefore suggest that the level of systemic risk during the financial crisis was higher for financial institutions with greater managerial risk-taking incentives.

Eight, we estimate parsimonious versions of the regressions with Size, Capital ratio, and Return on assets as the only control variables to ascertain that our findings are not driven by spurious correlations between the variables used in the regressions. Again, the coefficients for the variables of interest (not tabulated) are consistent with our main analysis. Our parsimonious regressions indicate that managerial risk-taking incentives are generally negatively associated with systemic risk, while being significantly positively associated with the level of risk during the severe financial market turmoil in 2008.

Ninth, we investigate whether our findings are affected by firm-size effects. For this purpose, we divide our sample into two subsamples based on firm-size and then re-estimate the regressions (not tabulated). We exclude either the largest $10 \%$ or the smallest $10 \%$ of the financial institutions from the sample. The regressions results based on these two subsamples are very similar to the results reported in Tables 4 and 5 and the coefficients for the deltas and vegas as well as for the crisis interaction variables have the same signs and mostly the same significance levels as in our main regressions. This suggests that our 
empirical findings are not driven by the largest or the smallest institutions included in the sample.

Tenth, we examine the sensitivity of our results to the sample period used in the regressions. Specifically, we re-estimate the regressions using three different truncated subsamples (not tabulated). The first truncated subsample excludes the first sample year 2005, the second subsample excludes the crisis year 2008, and the third excludes the last sample year 2010. When either year 2005 or 2010 is excluded, the results are broadly consistent with the estimates reported in Table 4 and 5, and indicate that financial institutions with greater managerial risk-taking at the onset of the financial crisis incentives were associated with higher MES and SRISK during the crisis in 2008. When we exclude the crisis year 2008 from the sample, the coefficient estimates for CEO vega and CFO vega are negative and statistically highly significant both in the MES and SRISK regressions, and the coefficients for $C E O$ delta and $C F O$ delta are statistically insignificant. This provides additional evidence that the sensitivities of top executive compensation to stock return volatility are negatively associated with the systemic risk of financial institutions, at least outside crisis periods.

Eleventh, in order to further examine the effects of the financial crisis on our findings, we exclude "troubled" financial institutions from the sample and then re-estimate the regressions (not tabulated). We define "troubled" financial institutions as those institutions that either failed or reported losses in excess of $2 \%$ of total assets during the crisis. The regression results without the "troubled" institutions are very similar to the estimates reported in Tables 4 and 5. The overall association between managerial risk-taking incentives and systemic risk is negative, and the positive and statistically significant coefficients for Delta $\times$ Year $^{2008}$ and Vega $\times$ Year $^{2008}$ indicate that financial institutions with greater managerial risk-taking incentives were positively associated with systemic risk amidst the crisis in 2008.

Finally, given that our sample contains different types of financial institutions, we examine the robustness of our results by restricting the sample to commercial banks and other lending institutions with a net loans to total assets ratio of at least $30 \%$. When the regressions are re-estimated with this restricted sample (not tabulated), the results are similar to our main analysis. Once again, the coefficients for the interaction variables Delta $\times Y_{\text {Year }}{ }^{2008}$ and Vega $\times$ Year $^{2008}$ are positive and statistically significant both in the MES and SRISK regressions, and therefore suggest that the pre-crisis risk-taking incentives of the top executives are positively association with systemic risk during the crisis. Thus, we conclude that our results are robust to the exclusion of investment banks and non-bank financial services firms from the sample.

\section{Conclusions}

Politicians, regulators, and bank supervision authorities have emphasized the focal role of executive compensation policies at banking organizations in the development of the global financial crisis of 2008-2009. Moreover, the financial crisis highlighted the importance of systemic risk and the fact that risk-taking of individual institutions may create substantial negative externalities on the financial system. In this paper, we examine the linkage between systemic risk and compensation-based risk-taking incentives of the top executives. The risk-taking incentives generated by executive compensation programs are generally designed to maximize shareholder value by mitigating managerial risk aversion. However, 
given the moral hazard problems caused by the too-big-to-fail phenomenon, implicit and explicit government guarantees, and deposit insurance systems, greater alignment of incentives between executives and shareholders may encourage excessive risk-taking in the financial industry.

In our empirical analysis, we use data on large, publicly traded U.S. financial institutions to empirically examine whether systemic risk is associated with the risk-taking incentives generated by executive compensation. We measure the risk-taking incentives of CEOs and CFOs with the sensitivities of their personal compensation to changes in the stock price and stock return volatility of their institutions. Furthermore, we use the marginal expected shortfall (MES) and systemic risk (SRISK) proposed by Acharya et al. (2012, 2017), and Brownlees and Engle (2017) to gauge the systemic risk of individual financial institutions. $M E S$ and SRISK provide a measure of the exposure of a given financial institution to aggregate tail shocks in the financial system.

We find an ambiguous relationship between managerial risk-taking incentives and systemic risk. Our empirical findings indicate that the sensitivities of top executive compensation to volatility are generally negatively associated with systemic risk, while the relation between executive pay-performance sensitivity and systemic risk is virtually nonexistent. These findings are in stark contrast with the hypothesis that greater compensation-based managerial risk-taking incentives would increase the level of systemic risk. Nevertheless, the documented negative association between vegas and banks' systemic risk is broadly consistent with the less recognized alternative view that compensation-based risk-taking incentives may induce risk-averse executives to adopt less risky policies. Our empirical findings also demonstrate that the relationship between managerial risk-taking incentives and banks' systemic risk is not stable over time. We find that financial institutions with greater managerial risk-taking incentives were associated with significantly higher levels of systemic risk in 2008 during the global financial crisis. Our estimates suggest that one standard deviation increases in the pre-crisis risk-taking incentives increase MES by about $25-40$ basis points and SRISK by several percentage points during the crisis. This positive association between $\mathrm{CEO}$ and $\mathrm{CFO}$ risk-taking incentives and systemic risk during the severe market turmoil in 2008 may indicate that financial institutions with greater compensation-based risk-taking incentives were taking more risk before the crisis in order to maximize shareholder wealth, and that these risks were then materialized and exposed during the financial crisis.

Acknowledgements Open access funding provided by the University of Vaasa. We would like to thank an anonymous referee, Miguel García-Cestona, Jim Gilkeson, Denis Davydov, Iftekhar Hasan, Jana Ohls, Laura Rondi, Jukka Sihvonen, and conference and seminar participants at the 30th Australasian Finance and Banking Conference, the 19th Corporate Governance and Investment Workshop, the Hanken School of Economics Workshop on Corporate Governance, the University of Vaasa Banking Research Workshop, and the University of Vaasa for helpful comments and suggestions. J. Iqbal gratefully acknowledges the support of the Marcus Wallenberg Foundation and the Finnish Cultural Foundation. S. Vähämaa gratefully acknowledges the support of the OP Group Research Foundation and the Finnish Savings Banks Research Foundation.

Open Access This article is distributed under the terms of the Creative Commons Attribution 4.0 International License (http://creativecommons.org/licenses/by/4.0/), which permits unrestricted use, distribution, and reproduction in any medium, provided you give appropriate credit to the original author(s) and the source, provide a link to the Creative Commons license, and indicate if changes were made. 


\section{Appendix 1}

List of financial institutions

\begin{tabular}{|c|c|c|c|}
\hline 1 & American Express & 39 & Metlife \\
\hline 2 & Associated Banc-Corp. & 40 & Morgan Stanley \\
\hline 3 & Bank of America & 41 & National City \\
\hline 4 & Bank of Hawaii & 42 & New York Community Bancorp \\
\hline 5 & Bank of New York Mellon & 43 & Northern Trust \\
\hline 6 & $\mathrm{BB} \& \mathrm{~T}$ & 44 & PNC Financial Services \\
\hline 7 & BBVA Compass Bancshares & 45 & Principal Financial Group \\
\hline 8 & Bear Stearns & 46 & Prosperity Bancshares \\
\hline 9 & BGC Partners & 47 & Prudential Financial \\
\hline 10 & BOK Financial & 48 & Raymond James Financial \\
\hline 11 & Capital One Financial & 49 & Regions Financial \\
\hline 12 & Capitol Federal Financial & 50 & SEI Investments \\
\hline 13 & Charles Schwab & 51 & Signature Bank \\
\hline 14 & Citigroup & 52 & Sallie Mae \\
\hline 15 & City National & 53 & Sovereign Bank \\
\hline 16 & Comerica & 54 & State Street \\
\hline 17 & Commerce Bancshares & 55 & Stifel Financial \\
\hline 18 & Countrywide & 56 & SunTrust \\
\hline 19 & Cullen/Frost Bankers & 57 & SVB Financial \\
\hline 20 & East West Bancorp & 58 & Synovus Financial \\
\hline 21 & Fannie Mae & 59 & T. Rowe Price Group \\
\hline 22 & Fifth Third Bancorp & 60 & TCF Financial \\
\hline 23 & First Citizens BancShares & 61 & TD Ameritrade \\
\hline 24 & First Horizon National & 62 & TransAtlantic \\
\hline 25 & First Niagara Financial & 63 & UMB Financial \\
\hline 26 & Franklin Resources & 64 & UnionBanCal \\
\hline 27 & Fulton Financial & 65 & US Bancorp \\
\hline 28 & Goldman Sachs & 66 & Valley National Bancorp \\
\hline 29 & Hancock & 67 & Washington Federal \\
\hline 30 & Hudson City Bancorp & 68 & Webster Financial \\
\hline 31 & Jefferies Group & 69 & Wells Fargo \\
\hline 32 & JP Morgan Chase \& Co. & 70 & WMI Holdings \\
\hline 33 & KeyCorp & 71 & Zions Bancorporation \\
\hline 34 & Legg Mason & & \\
\hline 35 & Lehman Brothers & & \\
\hline 36 & M\&T Bank & & \\
\hline 37 & Marshall \& Ilsley & & \\
\hline 38 & Merrill Lynch \& Co. & & \\
\hline
\end{tabular}




\section{References}

Acharya V (2009) A theory of systemic risk and design of prudential bank regulation. J Financ Stab $5: 224-255$

Acharya V (2011) Systemic risk and macro-prudential regulation. Working Paper, New York University

Acharya V, Thakor AV (2016) The dark side of liquidity creation: leverage and systemic risk. J Financ Intermed 28:4-21

Acharya V, Engle R, Richardson M (2012) Capital shortfall: a new approach to ranking and regulating systemic risks. Am Econ Rev 102:59-64

Acharya V, Pedersen LH, Philippon T, Richardson M (2017) Measuring systemic risk. Rev Financ Stud 30:2-47

Adams RB, Mehran H (2012) Bank board structure and performance: evidence for large bank holding companies. J Financ Intermed 21:243-267

Ahmed S, Sihvonen J, Vähämaa S (2019) CEO facial masculinity and bank risk-taking. Personal Individ Differ 138:133-139

Akhigbe A, Martin AD, Whyte AM (2016) Dodd-Frank and risk in the financial services industry. Rev Quant Finance Acc 47:395-415

Alam P, Liu M, Liu Z, Peng X (2015) Stock options, idiosyncratic volatility, and earnings quality. Rev Pacific Basin Financ Mark Policies 18:1-30

Anginer D, Demirguc-Kunt A, Zhu M (2014) How does competition affect bank systemic risk? J Financ Intermed 23:1-26

Armstrong CS, Vashishtha R (2012) Executive stock options, differential risk-taking incentives, and firm value. J Financ Econ 104:70-88

Bai G, Elyasiani E (2013) Bank stability and managerial compensation. J Bank Finance 37:799-813

Basel Committee on Banking Supervision (2010) Principles for enhancing corporate governance. Bank for International Settlements, Basel

Battaglia F, Gallo A (2017) Strong boards, ownership concentration and EU banks' systemic risk-taking: evidence from the financial crisis. J Int Financ Mark Inst Money 46:128-146

Bebchuk LA, Spamann H (2010) Regulating bankers’ pay. Georget Law J 98:247-287

Bebchuk LA, Cohen A, Spamann H (2010) The wages of failure: executive compensation at Bear Stearns and Lehman 2000-2008. Yale J Regul 27:257-282

Berger A, Roman R, Sedunov J (2016) Do bank bailouts reduce or increase systemic risk? The effects of TARP on financial system stability. Federal Reserve Bank of Kansas City Research Working Papers, No. 16-08

Bhagat S, Bolton B (2014) Financial crisis and bank executive incentive compensation. J Corp Finance 25:313-341

Bharati R, Jia J (2018) Do bank CEOs really increase risk in vega? Evidence from a dynamic panel GMM specification. J Econ Bus 99:39-53

Bisias D, Flood M, Lo AW, Valavanis S (2012) A survey of systemic risk analytics. Ann Rev Financ Econ 4:255-296

Board of Governors of the Federal Reserve System (2009a) Federal reserve issues proposed guidance on incentive compensation. Press release on October 22, 2009

Board of Governors of the Federal Reserve System (2009b) Proposed guidance on sound incentive compensation policies. Fed Reg 74(206):55227-55238

Board of Governors of the Federal Reserve System (2010) Bank holding company supervision manual, supplement 38. Board of Governors of the Federal Reserve System, Washington, DC

Brownlees C, Engle RF (2017) SRISK: a conditional capital shortfall measure of systemic risk. Rev Financ Stud 30:48-79

Brunnermeier M, Dong G, Palia D (2012) Banks' non-interest income and systemic risk. Working paper, Princeton University

Calluzzo P, Dong GN (2015) Has the financial system become safer after the crisis? The changing nature of financial institution risk. J Bank Finance 53:233-248

Carpenter JN (2000) Does option compensation increase managerial risk appetite? J Finance 55:2311-2331

Chakraborty A, Gao LS, Sheikh S (2018) Managerial risk taking incentives, corporate social responsibility and firm risk. J Econ Bus (forthcoming)

Chava S, Purnanandam A (2010) CEOs versus CFOs: incentives and corporate policies. J Financ Econ 97:263-278

Chen CR, Steiner TL, Whyte AM (2006) Does stock option-based executive compensation induce risk-taking? An analysis of the banking industry. J Bank Finance 30:915-945

Coles JL, Daniel ND, Naveen L (2006) Managerial incentives and risk-taking. J Financ Econ 79:431-468

Core J, Guay W (2002) Estimating the value of employee stock option portfolios and their sensitivities to price and volatility. J Acc Res 40:613-630 
Croci E, Petmezas D (2015) Do risk-taking incentives induce CEOs to invest? Evidence from acquisitions. J Corp Finance 32:1-23

de Haan J, Vlahu R (2016) Corporate governance of banks: a survey. J Econ Surv 30:228-277

DeYoung R, Peng EY, Yan M (2013) Executive compensation and business policy choices at U.S. commercial banks. J Financ Quant Anal 48:165-196

Doukas JA, Mandal S (2018) CEO risk preferences and hedging decisions: a multiyear analysis. J Int Money Finance 86:131-153

Ellul A, Yerramilli V (2013) Stronger risk controls, lower risk: evidence from U.S. bank holding companies. J Finance 68:1757-1803

Erkens DH, Hung M, Matos P (2012) Corporate governance in the 2007-2008 financial crisis: evidence from financial institutions worldwide. J Corp Finance 18:389-411

Fahlenbrach R, Stulz RM (2011) Bank CEO incentives and the credit crisis. J Financ Econ 99:11-26

Feng H, Rao RP (2018) Cash holdings and CEO risk incentive compensation: effect of CEO risk aversion. Int Rev Financ Anal 60:162-176

Foos D, Norden L, Weber M (2010) Loan growth and riskiness of banks. J Bank Finance 34:2929-2940

Fortin R, Goldberg GM, Roth G (2010) Bank risk taking at the onset of the current banking crisis. Financ Rev 45:891-913

Gande A, Kalpathy S (2017) CEO compensation and risk-taking at financial firms: evidence from U.S. federal loan assistance. J Corp Finance 47:131-150

Grundke P (2018) Ranking consistency of systemic risk measures: a simulation-based analysis in a banking network model. Rev Quant Finance Acc (forthcoming)

Guay WR (1999) The sensitivity of CEO wealth to equity risk: an analysis of the magnitude and determinants. J Financ Econ 53:43-71

Guo L, Jalal A, Khaksari S (2015) Bank executive compensation structure, risk taking and the financial crisis. Rev Quant Finance Acc 45:609-639

Hattori A, Kikuchi K, Niwa F, Uchida Y (2014) A survey of systemic risk measures: Methodology and application to the Japanese market. Bank of Japan IMES Discussion Paper No. 2014-E-3

Hayes RM, Lemmon M, Qiu M (2012) Stock options and managerial incentives for risk taking: evidence from FAS 123R. J Financ Econ 105:174-190

Hu C, Jiang W (2018) Managerial risk incentives and accounting conservatism. Rev Quant Finance Acc (forthcoming)

Iqbal J, Strobl S, Vähämaa S (2015) Corporate governance and the systemic risk of financial institutions. J Econ Bus 82:42-61

Jensen MC, Meckling WH (1976) Theory of the firm: managerial behavior, agency costs and ownership structure. J Financ Econ 3:305-360

Kini O, Williams R (2012) Tournament incentives, firm risk, and corporate policies. J Financ Econ 103:350-376

Kirkpatrick G (2009) The corporate governance lessons from the financial crisis. Working paper, OECD

Kleinow J, Moreira F, Strobl S, Vähämaa S (2017) Measuring systemic risk: a comparison of alternative market-based approaches. Finance Res Lett 21:40-46

Laeven L, Levine R (2009) Bank governance, regulation and risk taking. J Financ Econ 93:259-275

Mayordomo S, Rodriguez-Moreno M, Peña JI (2014) Derivatives holdings and systemic risk in the U.S. banking sector. J Bank Finance 45:84-104

Mehran H, Morrison A, Shapiro J (2011) Corporate governance and banks: What have we learned from the financial crisis? Staff report, Federal Reserve Bank of New York

Meulbroek LK (2001) The efficiency of equity-linked compensation: understanding the full cost of awarding executive stock options. Financ Manage 30:5-44

Minhat M, Abdullah M (2016) Bankers' stock options, risk-taking and the financial crisis. J Financ Stab 22:121-128

Pais A, Stork PA (2013) Bank size and systemic risk. Eur Financ Manage 19:429-451

Palia D, Porter R (2004) The impact of capital requirements and managerial compensation on bank charter value. Rev Quant Finance Acc 23:191-206

Palvia A, Vähämaa E, Vähämaa S (2015) Are female CEOs and Chairwomen more conservative and risk averse? Evidence from the banking industry during the financial crisis. J Bus Ethics 131:577-594

Pathan S (2009) Strong boards, CEO power and bank risk-taking. J Bank Finance 33:1340-1350

Peni E, Vähämaa S (2012) Did good corporate governance improve bank performance during the financial crisis? J Financ Serv Res 41:19-35

Peni E, Smith S, Vähämaa S (2013) Bank corporate governance and real estate lending during the financial crisis. J Real Estate Res 35:313-343 
Rajgopal S, Shevlin T (2002) Empirical evidence on the relation between stock option compensation and risk taking. J Acc Econ 33:145-171

Ross SA (2004) Compensation, incentives, and the duality of risk aversion and riskiness. J Finance 59:207-225

Serfling MA (2014) CEO age and the riskiness of corporate policies. J Corp Finance 25:251-273

Shaw KW (2012) CEO incentives and the cost of debt. Rev Quant Finance Acc 38:323-346

Yung K, Chen C (2018) Managerial ability and firm risk-taking behavior. Rev Quant Finance Acc 51:1005-1032 